Elisângela Pereira de Souza Quedas

\title{
Análise do proto-oncogene $R E T$ em pacientes com carcinoma medular de tireóide e megacólon congênito de uma família com mutação germinativa p.C620R
}

Dissertação apresentada à Faculdade de Medicina da Universidade de São Paulo para obtenção do Título de Mestre em Ciências

Programa de: Endocrinologia

Orientador: Prof. Dr. Sergio Pereira de Almeida Toledo

São Paulo

2011 
"A mente que se abre a uma nova idéia jamais voltará ao seu tamanho original."

(Albert Einstein) 


\section{Dedicatória}




\section{Dedicatória}

Dedico este trabalho aos meus pais, Alize e Elson, dos quais me orgulho pelo exemplo de humildade, perseverança, simplicidade $\mathrm{e}$ determinação, por sempre se esforçarem tanto para me dar o melhor, por me ensinarem a diferenciar o certo e o errado, por aceitarem minhas opiniões diferentes, por me darem apoio para estudar e me incentivarem a estudar mais do que eles puderam, com certeza influenciando assim no meu crescimento humano e profissional.

Ao homem da minha vida, meu marido Fauze, que acompanhou todo o desenvolvimento deste trabalho, incentivando-me em cada conquista e me ajudando a enfrentar todas as dificuldades por ela imposta, trazendo alegria e amor para meus dias, tornando possível a conclusão deste trabalho.

A minha filha Camila, por toda ajuda, força e apoio que me deu durante este período, por me dar tanto orgulho sendo uma excelente filha e aluna, por estar a 5 anos fazendo parte dos coros infantil e juvenil da OSESP, por ser a melhor pianista para mim e por encher a minha vida de cor, música e alegria.

Ao meu genrrinho Raphael, que com seu bom coração, caráter, inteligência e força de vontade, já se tornou uma pessoa muito querida e especial e que junto com minha filha, alegram meus dias.

Aos meus filhos que não são de barriga e sim de alma e coração: Betty, Filipe, Rebeca, Davi, Gustavo e Nicole, que embora não sejam "Toddynho", sempre foram meus companheiros de aventura.

Aos meus familiares e amigos (FIG, USP, FMUSP e IPJT) que às vezes mesmo estando distantes, me incentivaram a lutar e todos juntos fizeram valer a pena. 
Agradecimentos 


\section{Agradecimentos}

Foram tantas as ajudas preciosas e o empenho das pessoas envolvidas nesse trabalho que é com grande alegria que venho agradecer especialmente a cada uma delas.

Agradeço ao meu Deus, que me capacita dia a dia e da sentido a minha vida!

Agradeço ao meu orientador, Professor Doutor Sergio P. A. Toledo, por ter acreditado em mim e ter possibilitado a realização deste sonho, me presenteando com material para realizar esta tese. Pela orientação prestada, pelos conhecimentos científicos que me transmitiu ao longo destes anos de trabalho no laboratório, com acesso a uma abundante riqueza de conhecimentos e o envolvimento cada vez maior com a pesquisa científica, pela amizade, além do exemplo de exímio profissionalismo e competência, o meu mais profundo agradecimento.

Ao amigo (e meu orientador informal) Rodrigo Toledo, que conheci durante a sua graduação na USP, muito antes de sonhar entrar na UEG como funcionária ou aluna, por todo auxílio prestado no decorrer deste trabalho, pelos ensinamentos, conselhos e puxões de orelha, pelas risadas e pela companhia nos almoços no bandejão. Aprendi muito com você e te admiro bastante pelo seu caráter, sua dedicação em tudo que faz e por sua simplicidade no transmitir e compartilhar conhecimento.

Aos meus pais Alize e Elson, sempre presentes em minha vida. Amo vocês...

Ao meu marido Fauze que com seu amor incondicional me ajudou em todos os momentos que mais precisei. Agüentou-me mal humorada quando alguma coisa saia errado e compartilhava comigo minha alegria quando tudo dava certo. Te amo Fauzinho. 
A minha filha Camila por me ajudar sempre e suportar minhas crises de mal humor e estresse. Amo você, sua música me enche de alegria.

Ao meu genrrinho Raphael que soube compreender meus momentos de estresse e ajudou sempre da melhor maneira possível tentando me alegrar.

Aos meus filhos de coração: Betty, Filipe, Rebeca, Davi, Gustavo e Nicole, vocês são a minha alegria. Meu maior prazer é abrir a temporada de férias na casa da "Nana". Amo vocês...

A todos os meus familiares e amigos da IPJT pelo carinho e apoio sempre.

A todos os pacientes e familiares que tornaram possível a realização deste trabalho.

A amiga Maria das Graças Cavalcanti, a quem chamo carinhosamente de meu anjo da guarda, e as coletas de campo que ela realizou com suas mãos mágicas trazendo meus ricos DNAs para que eu pudesse trabalhar. Seu amor pelos pacientes e a dedicação com que faz seu trabalho perfeito é uma inspiração para mim... é uma honra trabalhar com ela!

A amiga de todas as horas: Michelle, pela companhia nas aulas, pela ajuda no laboratório, pelo incentivo nos momentos em que às vezes eu estava me sentido triste e desanimada, pelas gostosas risadas que compartilhamos, pelo calor humano no metrô lotado e pela companhia nos almoços do bandejão.

As amigas de trabalho Eliete e Geni com quem passo grande parte do meu dia, uma vez que além de aluna sou também funcionária do laboratório, agradeço pelo bom relacionamento, pela ajuda e incentivo, pelas risadas e momentos de descontração. Formamos uma ótima equipe de trabalho!

A Dra. Joya que carinhosamente me ensinou a ler e entender de verdade um artigo científico e sempre me auxiliou quando eu não entendia 
muito bem a parte clínica dos mesmos, pela convivência agradável e por ser uma aluna tão aplicada durante as minhas aulas de Biologia molecular para ela, Geni e Roxanne.

Aos amigos da Unidade e colegas do LIM25: a Viviane e a Tomoko pela ajuda prestada nos momentos em que eu mais precisava (dentro e fora do laboratório) e também pelos bons conselhos, a Dra. Flávia, a Dra. Tatiane, Dr. Delmar pelo apoio e incentivo constante e ajuda na parte clínica, a Roxanne e o Lucas pela ajuda e pelos géis de agarose.

As alunas de Pós graduação e Iniciação científica: Dra. Ândria, Dra. Ana Canton, Dra. Gabriela e Ana Jung, por serem tão aplicadas e dedicadas em minhas aulas de Biologia molecular. Tenho certeza que seus projetos serão muito bem sucedidos se vocês continuarem assim.

A Dra. Suemie pelas sugestões em minha qualificação e pelo carinho, sempre pronta a ajudar e a amiga Eliana pela ajuda, apoio e incentivo sempre, não só no seqüenciador como em tudo que eu precisava.

Ao amigo Marco, pela ajuda com o seqüenciador, com as precipitações e por sempre estar torcendo por mim, me apoiando e me motivando sempre. É muito bom trabalhar com você, acho que formamos uma ótima equipe de trabalho. Desejo do fundo do coração que você encontre a sua "pergunta interior" e consiga realizar seu sonho e atingir seus objetivos assim como eu consegui alcançar o meu.

As meninas do "laboratório vizinho" (grupo Tireóide - LIM25): Ester, Ana Luiza, Erika e Paola, pelo convívio agradável, pelo socorro nos momentos em que faltava algum material ou eu não conseguia fazer alguma tabela e gráfico... pelas risadas e companhia nos almoços do bandejão e finais de semana. A Dra. lleana pela sugestões na minha qualificação e pelo carinho. 
Ao meu chefe Dr. Alexander Augusto de Lima Jorge pela compreensão e incentivo na fase final deste trabalho, pelas sugestões na qualificação e por acreditar em mim.

A Professora Dra. Berenice B. A. Mendonça pelo apoio e incentivo sempre.

Ao Dr. Uenis Tanuri pelas informações e aulas sobre Hirschsprung ao qual tive o privilégio de assistir com ele, pelo incentivo ao meu trabalho e por toda sua colaboração.

Aos amigos inesquecíveis da minha graduação (FIG): Daniela, Beth Magagnin, Enivaldo (Baixinho), Célio (Xerife), Kelly (que me levou para USP), e Sininho (Sindy), assim como os meus amigos do IB-USP onde comecei minha história: a Prof ${ }^{-}$Maria Rita Passos Bueno que me ensinou pessoalmente a lavar as placas do ABI377 e fazer um gel quando seqüenciávamos a Xyllela fastidiosa e a fazer minha primeira $\mathrm{PCR}$, a Toninha por compartilhar comigo seu conhecimento em Biomol, pelas caronas e por sua alegria contagiante, Paula, Kikue, Dulce, Constancia, Andrea Bernardino, Carlos, Cristiane (loira), Agnes, Manuela, Lucia, Alex Esplendore, Luciana, Cyntia (In memórian), Flavinha, Paty, Renatão, Camila, Prof ${ }^{a}$ Cris Miyaki, Telma, Leila, Priscila, Carminha, Silvia, Erika, Beth Teodorov, Ivone, Luciana Terumi, Adriana, Jonathan, Prof ${ }^{\underline{a}}$ Marie Anne, Prof ${ }^{\text {a }}$ Mariana Cabral (e todos os outros que também passaram pela minha vida e deixaram suas marcas), pelo convívio agradável, pelo socorro nos momentos em que eu precisava, pelo consolo nos momentos de tristeza, pelas risadas, pelos ensinamentos preciosos e pela companhia. Posso não estar sempre presente como eu gostaria, mas amo todos vocês do fundo do meu coração...vocês sempre serão especiais para mim!!

Com eles divido a felicidade na concretização desta Dissertação de Mestrado. Minha eterna gratidão. 


\section{Sumário}

Lista de Abreviaturas

Lista de Figuras

Lista de Quadros

Resumo

Sumary

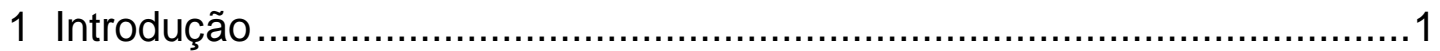

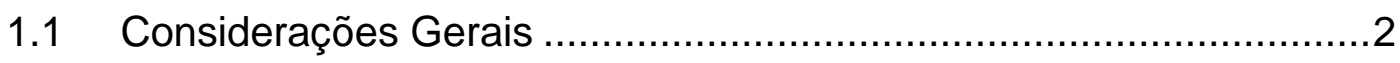

1.2 Neoplasia Endócrina Múltipla Tipo 2 (MEN2) ..................................

1.2.1 Definição ..................................................................

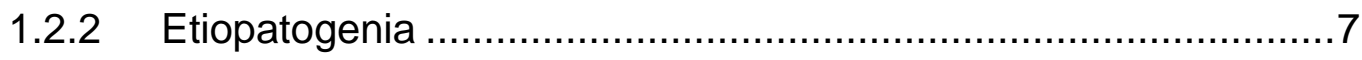

1.2.3 Carcinoma medular de tireóide associado à NEM2 (CMT/MEN2) ….....................................................................

1.2 .4 Feocromocitoma....................................................... 13

$1.2 .5 \quad$ Hiperparatireoidismo ......................................................... 14

1.2.6 Outros Fenótipos............................................................ 15

1.2.7. Aspectos moleculares do RET ......................................... 16

1.2.8 Variabilidade clínica .........................................................23

1.2.9 Polimorfismos / Dupla Mutações ..............................................23

1.3 Hirschsprung ou Megacólon congênito.....................................26

1.3.1 Introdução .....................................................................26

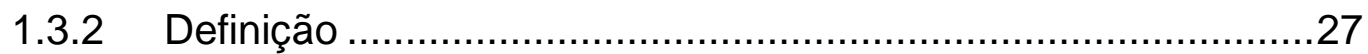

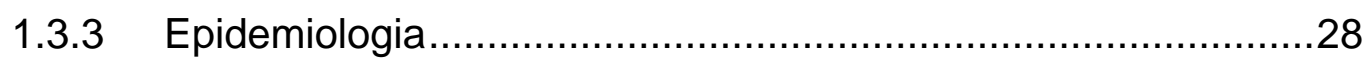

1.3.4 Apresentação Clínica .........................................................29

1.3.5 Diagnóstico ..................................................................... 30

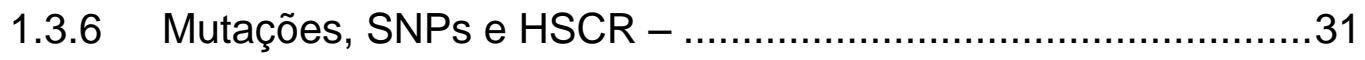

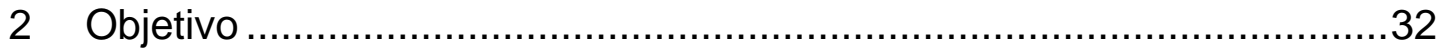

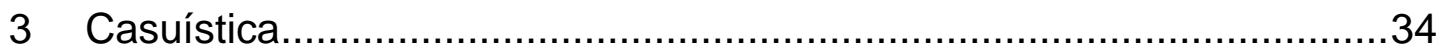




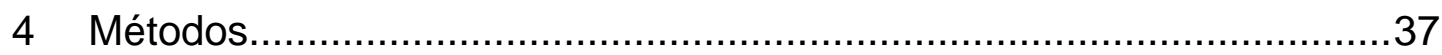

4.1 Extração de DNA a partir de sangue periférico.................................38

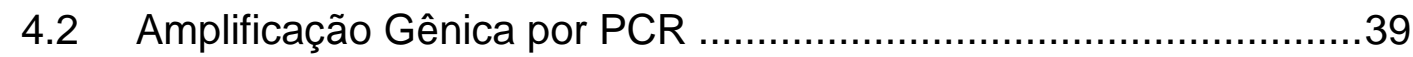

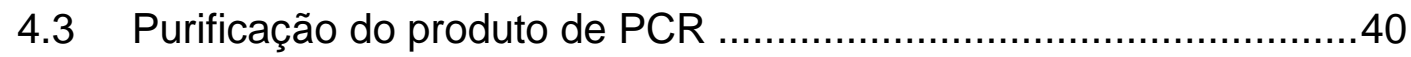

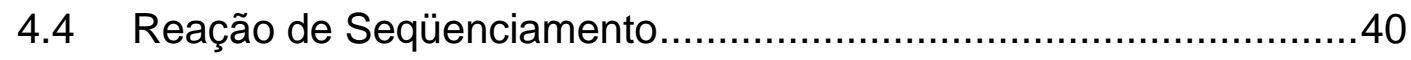

4.5 Protocolo de Precipitação das amostras para Seqüenciamento......41

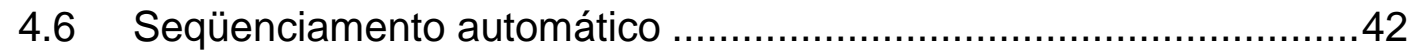

4.7 Análise do seqüenciamento .................................................... 42

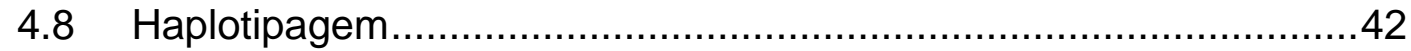

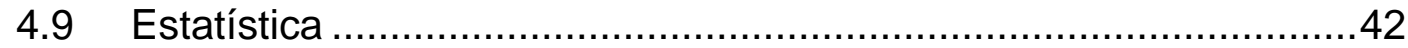

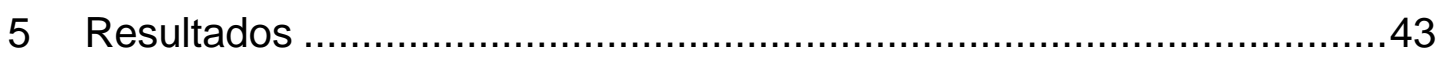

5.1 Análise da região codificadora do gene RET em pacientes com

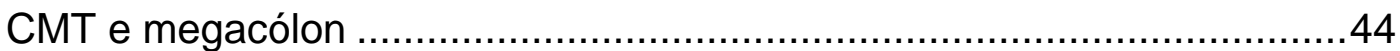

5.2 Identificação de polimorfismos no gene RET em heterozigose

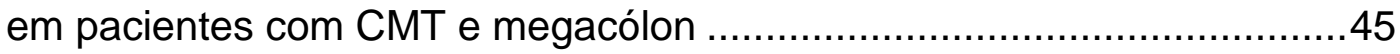

5.3 Identificação de haplótipos no gene RET em pacientes com CMT e megacólon .50

5.4 O haplótipo TTCGTTAAAGC co-segrega com o fenótipo de megacólon nos ramos HSCR-1 e HSCR-2 da família com a mutação RET p.C620R

5.5 Análise de outros familiares com a mutação RET p.C620R com e sem megacólon para comparação dos haplótipos.

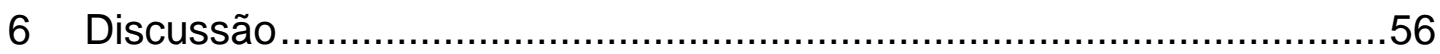

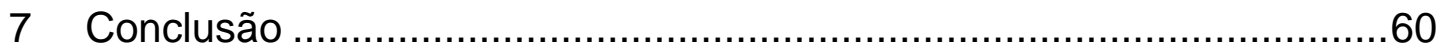

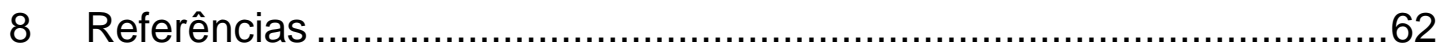




\section{Lista de Abreviaturas}

$\begin{array}{ll}\text { CMT } & \text { carcinoma medular de tireóide } \\ \text { FEO } & \text { feocromocitoma } \\ \text { FMUSP } & \text { Faculdade de Medicina da Universidade de São Paulo } \\ \text { HC } & \text { Hospital das Clínicas } \\ \text { HPT } & \text { hiperparaitiodismo primario } \\ \text { HSCR } & \text { hirschsprung } \\ \text { MEN } & \text { neoplasia endócrina múltipla } \\ \text { NEMs } & \text { neoplasias endócrinas multiplas } \\ \text { NEM2 } & \text { neoplasia endocrina múltipla tipo } 2 \\ \text { PCR } & \text { Polymerase Chain Reaction } \\ \text { TSH } & \text { hormônio tireo - estimulante }\end{array}$




\section{Lista de Figuras}

Figura 1: O diagnóstico molecular do $R E T$ tem papel fundamental na conduta clínica e no tratamento cirúrgico de pacientes com NEM-2.

Figura 2: Correlação genótipo-fenótipo na NEM-2

Figura 3: A seta indica a mutação germinativa encontrada na família estudada: uma troca do nucleotídeo T por um C (c.1858T>C, éxon 10), levando a uma troca do aminoácido cisteína por uma arginina

Figura 4: Além da mutação ativadora p.C620R no éxon 10, nenhuma outra variante patogência foi identificada nos éxons 1-20 do gene RET em pacientes com a mutação ativadora p.C620R, que desenvolveram megacólon congênito

Figura 5: Polimorfismo c.74-1454T>C (rs2505533) no íntron 1 do gene RET.

Figura 6: Polimorfismo c.74-1379T>A no íntron 1 do gene RET

Figura 7: Polimorfismo c.74-1362C >T (rs2505532) no íntron 1 do gene RET.

Figura 8: Polimorfismo c.74-1329G >A (rs72781232) no íntron 1 do gene RET.

Figura 9: Polimorfismo c.74-1290T>C (rs2505531) no íntron 1 do gene RET.

Figura 10: Polimorfismo c.74-126G>T (rs2565206) no íntron 1 do gene RET

Figura 11: Polimorfismo c. $1522+58 \mathrm{C}>\mathrm{A}$ no íntron 7 do gene $R E T$. 50

Figura 12: Haplótipo associado à mutação p.C620R

Figura 13: Haplótipo compartilhado pelos 2 irmãos sem megacólon do ramo HSCR-1 da família.

Figura 14: Haplótipo apresentado pelo irmão com megacólon, do ramo HSCR-1 da família 
Figura 15: Dados clínicos e genéticos de dois ramos da família com a mutação RET p.C620R e megacólon (HSCR-1 e HSCR-2) são mostrados.

Figura 16: Os haplótipos de seis familiares com mutação RET p.C620R e que não desenvolveram megacólon são mostrados. 55 


\section{Lista de Quadros}

Quadro 1: As Neoplasias Endócrinas Múltiplas são classificadas de acordo com as glândulas afetadas e com o gene envolvido.........6

Quadro 2: Classificação das NEM2 de acordo com as combinações dos fenótipos envolvidos nessa síndrome

Quadro 3: Diferenças entre as formas herdada e esporádica de CMT ........10

Quadro 4: Diferenças entre FEO/NEM-2 e FEO esporádico .14

Quadro 5: Classificação/categorias de risco de CMT de acordo com a mutação $R E T$.

Quadro 6: Variantes do gene RET identificadas em heterozigose em pacientes com mutação p.C620R, com e sem megacólon .........46 
Resumo 


\section{Resumo}

Quedas E. Análise do proto-oncogene RET em pacientes com carcinoma medular de tireóide e megacólon congênito de uma família com mutação germinativa p.C620R [dissertação] São Paulo: Faculdade de Medicina, Universidade de São Paulo; 2011. 76p.

As Neoplasias endócrinas múltiplas (NEMs) são síndromes herdadas de modo dominante e causadas por mutações germinativas em genes específicos. Caracterizam-se pela presença de tumores em um conjunto de glândulas endócrinas, conjunto este típico de cada tipo-específico de NEM. Dentre os diferentes tipos de NEMs, há a neoplasia endócrina múltipla tipo 2 (NEM2) que envolve os fenótipos, carcinoma medular de tireóide (CMT), hiperparatiroidismo primário (HPT), feocromocitoma (FEO) e megacólon congênito (doença de Hirschsprung, HSCR). Apesar da prevalência da NEM2 na população em geral ser baixa ( 1:30.000), o número de casos afetados por família pode ser expressivo, uma vez que sua penetrância é praticamente completa ( 100\%). A doença de HSCR ou aganglionose intestinal congênita quando ocorre está geralmente associada à mutações RET nos códons 609, 618 e 620; apresenta ampla variação fenotípica, padrão de herança complexa e baixa penetrancia. Poucos casos de HSCR podem apresentar mutações em outros genes. Mutações no gene RET são responsáveis por aproximadamente metade $(\sim 50 \%)$ dos casos familiares de HSCR e alguns casos esporádicos ( 10-20\%), sugerindo fortemente que a HSCR seja doença poligenica. Tem-se também sugerido que polimorfismos genéticos no RET podem influenciar o fenotipo da NEM2/HSCR. No presente estudo, analisamos o gene RET no sentido de investigar se 0 desenvolvimento de megacólon em pacientes com a mutação germinativa RET p.C620R estaria associado à presença de ou a) a uma segunda mutação germinativa ou b) a um SNP, ou c) a um haplótipo informativo, que possivelmente poderia estar potencialmente interagindo genicamente com a mutação RET principal e eventualmente modulando o fenótipo HSCR.

Descritores: 1.Neoplasia endócrina múltipla tipo 2a 2.Feocromocitoma 3.Carcinoma medular de tireóide 4.Doença de Hirschsprung 5. Hiperparatireoidismo primário $6 . R E T$ 


\section{Summary}

Quedas E. Analysis of the RET proto-oncogene in patients with medullary thyroid cancer and congenital mega-colon in a family with germline mutation p.C620R [dissertation] São Paulo: "Faculdade de Medicina, Universidade de São Paulo"; 2011. 76p.

The multiple endocrine neoplasias (MENs) are inherited multi-tumoral conditions caused by germline mutations in specific genes. Specifically, the multiple endocrine neoplasia type 2 (NEM2) is a hereditary endocrine disorder transmitted dominantly and involving three main tumors, medullary thyroid carcinoma (CMT), primary hyperparathyroidism (HPT) and pheochromocytoma (PHEO). Despite the low prevalence of MEN2 in general population, the number of affected individuals per family can be significant as the penetrance of MEN2 is almost complete ( 100\%). In addition to CMT, PHEO and HPT, other conditions as congenital megacólon (Hirschsprung disease, HSCR or congenital intestinal aganglionosis) may occur in MEN2 (HSCR/MEN2). HSCR/MEN2 usually is due to RET mutations in codons 609, 618 and 620 . HSCR has a wide phenotypic variation; is a complex multigenic disease; and has a low penetrance. Mutations in the RET gene are responsible for approximately $50 \%$ of the familial HSCR cases and $\sim 10 \%$ of the sporadic HSCR cases, supporting that HSCR is a polygenic disease and this is confirmed by a few HSCR cases associated with mutations in the EDNRB and EDN3 genes. In the present study, we focused in the analysis of the RET gene in order to investigate whether the development of congenital megacólon in patients with RET mutation p.C620R is associated with the presence of, a) a second RET germline mutation, b) a SNP, or with a haplotype that co-segregate with the disease.

Descriptors: 1.Multiple Endocrine Neoplasia type 2 (MEN2) 2.CMT, PHEO, HPT, congenital megacólon, Hirschsprung 5.Aganglionosis 6.RET. 


\section{Introdução}




\subsection{Considerações Gerais}

Vivemos em um século onde os avanços e descobertas médicas, científicas e tecnológicas estão evoluindo de forma muito rápida. Conseqüentemente, o conhecimento da biologia molecular e celular acompanhou esta evolução, colaborando de maneira preponderante para a abordagem diagnóstica e terapêutica das doenças endócrino-hereditárias.

Como exemplo deste avanço, podemos citar o estudo das neoplasias endócrinas múltiplas (MENs). O rastreamento gênico das mutações responsáveis pelas MENs permitiu a identificação de pacientes portadores de mutação em idades bastante jovens, muitas vezes ainda sem a manifestação clínica da doença.

O diagnóstico e a intervenção terapêutica precoces nestas famílias freqüentemente permitiram a redução da morbilidade e mortalidade dos pacientes, bem como uma melhor qualidade de vida. Basicamente, estas síndromes são caracterizadas pela presença de mutações nas células germinativas capazes de transformar células endócrinas em células neoplásicas, seja pela perda de função de genes de supressão tumoral ou pela presença de mutações ativadoras em proto-oncogenes.

E é a ocorrência associada de tumores benignos e/ou malignos, envolvendo duas ou mais glândulas endócrinas que caracterizam as MENs (Marx, 2005). 


\subsection{Neoplasia Endócrina Múltipla Tipo 2 (MEN2)}

\subsubsection{Definição}

Em 1968, Steiner e cols. sugeriram o termo Neoplasia Endócrina Múltipla tipo 2 (MEN2; OMIM \#171400), para uma síndrome clínica caracterizada pela presença de CMT, Feo e HPT. Isto em contraposição à conhecida síndrome de Wermer ou neoplasia endócrina múltipla tipo 1(MEN1), que acomete as glândulas paratireóide, pâncreas e hipófise.

A MEN2 é uma endocrinopatia herdada por herança autossômica dominante. Apesar de sua prevalência na população ser baixa ( 1:20.000), o número de indivíduos afetados em cada uma das famílias pode ser expressivo uma vez que sua penetrância é praticamente completa ( 100\%). Assim, diante de cada paciente com CMT, FEO ou HPT deve-se levantar a hipótese de se tratar eventualmente de um caso com NEM2.

Estima-se que mais de $95 \%$ dos casos com NEM-2 possuam mutações germinativas no proto-oncogene RET (genelD $=5979, \mathrm{NCBI}$ ), havendo forte predominância de mutações nos éxons extracelulares, 10 e 11 (7; 4). Note-se que a imensa maioria das mutações no RET são do tipo missense (de Groot et al, 2006).

A MEN2 está subdividida em três subtipos básicos: neoplasia endócrina múltipla tipo 2A (MEN2A), tipo 2B (MEN2B) e CMT familiar (CMTF). Em aproximadamente $75 \%$ dos casos de MEN2 existe uma tríade característica de tumores designados por MEN2A ou Síndrome 
de Sipple: CMT (em aproximadamente 95\%) que geralmente é usualmente a primeira manifestação; Feo (em aproximadamente 50\%) e HPT ( 20 a 30\%).

Entretanto, existem variantes: MEN2A com megacólon congenito (doença de Hirschprung, HSCR) e MEN2A associada a amiloidose cutânea. A MEN2B é caracterizada por CMT de evolução agressiva, Feo, ganglioneuromas mucosos e ausencia de HPT.

No CMTF, o tumor medular da tireóide é a única manifestação sendo que para seu diagnóstico há necessidade da presença de um número superior a 10 afetados na mesma família e também múltiplos portadores com mais de 50 anos de idade (de Groot et al, 2006).

A MEN2 é causada por mutações germinativas no gene RET, as quais são responsáveis por todas as variantes clínicas da MEN2. O gene RET está localizado no cromossomo 10 (10q11. 2) e codifica um receptor do tipo tirosinaquinase, também denominado RET.

Há forte correlação genótipo-fenótipo na MEN2 e esta característica permite que a análise de mutação do RET seja usada como guia da conduta diagnóstica e terapêutica preventiva de casos com MEN2 e de seus parentes portadores de mutação e portanto sob-risco de apresentarem CMT. A maioria das mutações no gene RET estão localizadas nos éxons hot-spots extra-celulares: $10,11,13,14,15$ e 16.

Segundo os Consensos internacionais sobre NEMs (Brandi et al, 2001; Kloos et al, 2009), a) há recomendação de se realizar a análise de mutação no proto-oncogene RET em todos os pacientes com CMT e também em 
todos os pacientes com FEO, independentemente de serem casos esporádicos ou familiares; b) há recomendação para que seja realizada tireodectomia total preventiva em todos os portadores de mutação germinativa no RET, independentemente do quadro clínico apresentado (Brandi ML, 2001); c) a época recomendada para a cirurgia preventiva varia de acordo com códon mutado: antes dos 6 meses no MEN2B; ao redor dos 3 anos nas mutações no códon 634; antes dos 5 anos quando há mutações nos códons 620, 618, 609, entre outros; e antes dos 10 anos quando há mutações no códon 804, entre outros.

Sendo assim, o diagnóstico molecular na MEN2 se tornou de fundamental importância para o manejo clínico e terapeutico de pacientes com MEN2. Aproximadamente $25 \%-30 \%$ dos CMT ocorrem como parte integrante de uma MEN2, os restantes sendo casos de CMT esporádicos (Brandi et al, 2001de Groot et al, 2006).

Os vários tipos de MENs estão no quadro abaixo, sendo que na presente dissertação nos concentraremos na MEN2. 
Quadro 1: As Neoplasias Endócrinas Múltiplas são classificadas de acordo com as glândulas afetadas e com o gene envolvido

\begin{tabular}{|c|c|c|c|c|}
\hline NEM & Sigla & OMIM & $\begin{array}{l}\text { Glândulas } \\
\text { envolvidas }\end{array}$ & $\begin{array}{l}\text { Gene } \\
\text { envolvido }\end{array}$ \\
\hline $\begin{array}{l}\text { Neoplasia Endócrina } \\
\text { Múltipla tipo } 1\end{array}$ & NEM1A & 131100 & $\begin{array}{l}\text { Paratireóides } \\
\text { Hipófise anterior } \\
\text { Pâncreas } \\
\text { endócrino }\end{array}$ & MEN1 \\
\hline $\begin{array}{l}\text { Neoplasia Endócrina } \\
\text { Múltipla tipo } 1\end{array}$ & NEM1B & 131100 & $\begin{array}{l}\text { Paratireóides } \\
\text { Hipófise anterior }\end{array}$ & $C D K N 1 B$ \\
\hline $\begin{array}{l}\text { Neoplasia } \\
\text { Múltipla tipo } 2\end{array}$ & $\operatorname{NEM} 2 \mathrm{~A}(1)$ & 171400 & $\begin{array}{l}\text { Tireóide } \\
\text { Paratireóides } \\
\text { Adrenais }\end{array}$ & $R E T$ \\
\hline $\begin{array}{l}\text { Neoplasia Endócrina } \\
\text { Múltipla tipo } 2\end{array}$ & $\operatorname{NEM} 2 \mathrm{~A}(2)$ & 171400 & $\begin{array}{l}\text { Tireóide } \\
\text { Paratireóides }\end{array}$ & RET \\
\hline $\begin{array}{l}\text { Neoplasia Endócrina } \\
\text { Múltipla tipo } 2\end{array}$ & $\operatorname{NEM} 2 \mathrm{~A}(3)$ & 171400 & $\begin{array}{l}\text { Tireóide } \\
\text { Adrenais }\end{array}$ & $R E T$ \\
\hline Complexo de Carney & $\mathrm{CNC}$ & 160980 & $\begin{array}{l}\text { Tireóide } \\
\text { Hipófise anterior } \\
\text { Adrenais } \\
\text { Testículo }\end{array}$ & PRKAR1A \\
\hline Von Hippel Lindau & VHL & 193300 & $\begin{array}{l}\text { Adrenais } \\
\text { Pâncreas } \\
\text { endócrino }\end{array}$ & $V H L$ \\
\hline Neurofibromatose & NF & 162200 & $\begin{array}{l}\text { Paratireóides } \\
\text { Tireóide } \\
\text { Adrenais }\end{array}$ & $N F 1$ \\
\hline
\end{tabular}




\subsubsection{Etiopatogenia}

A MEN2 é uma neuro-cristopatia. Assim, sua origem da NEM-2 está relacionada à proliferação tumoral das células derivadas da crista neural: as células $\mathrm{C}$ da tireóide, células cromafins da medula das supra-renais, células principais e oxifílicas das paratireóides, gânglios simpáticos, parassimpáticos e entéricos, além do trato urogenital (Marx, 2005).

Assim, na NEM2 há aumento da produção e secreção de diversas substâncias hormonais e não-hormonais, de acordo com os tumores que se desenvolverem (Eng C, 1999).

\section{a) A NEM2 nas fases genômica e pré-genômica}

Antes da identificação da causa genética da NEM2 (fase prégenômica, pré-1993), o diagnóstico do CMT era realizado com base em critérios eminentemente clínicos, tais como: presença de nódulo tireoidiano geralmente único; dosagens do seu marcador tumoral do CMT (calcitonina) e do CEA; exames de imagem; e imunocitoquímica para a calcitonina em material citológico e/ou patológico (Abelin et al, 1999).

Frequentemente, o reconhecimento clínico do CMT/MEN2, FEO/MEN2 e HPT/MEN2 era realizado tardiamente, fato este que era associado à menor sobrevida e pior qualidade de vida desses pacientes (Gagel RF, 1991).

Após a identificação de mutações no proto-oncogene RET como sendo a causa genética da NEM2 (fase genômica, a partir de 1993), a MEN2 
passou a ser potencialmente diagnosticada de forma mais precoce por meio da análise genética do proto-oncogene RET (Mulligan LM, 1993; DonnisKeller H, 1993).

O impacto do diagnóstico molecular do RET na conduta clínica e cirúrgica da NEM-2 tem sido enorme, uma vez que o reconhecimento de portadores de mutação no gene RET abre a possibilidade de terapia cirúrgica precoce e eventualmente curativa (Toledo et al, Clinics).

Os Consensos internacionais sobre NEMs tanto do NIH como da ATA (Brandi ML, 2001, Kloos et al, 2009) recomendam a realização de tireoidectomia total preventiva em todos os portadores de mutação germinativa patogenica no RET, independentemente do quadro clínico apresentado. É fundamental também a realização do rastreamento genético de todos os familiares sob-risco, pois estes apresentam $50 \%$ de risco de terem herdado a mesma mutação e, conseqüentemente, apresentarem elevada predisposição à doença (Donnis-Keller H, 1993; Hoff AO, 2000; Wells SA Jr, 2000; Brandi ML, 2001).

Além disto, em cerca de 5-7\% de casos com CMT considerados inicialmente como casos esporádicos, documentou-se mutação germinativa no RET, assim como em cerca de 10\%-30 \% de todos os casos de FEO aparentemente esporádicos (Brandi ML, 2001; Neumann et 2002, N. Engl. J. Med). 


\section{b) Classificação clínica da NEM2}

Quadro 2: Classificação das NEM2 de acordo com as combinações dos fenótipos envolvidos nessa síndrome

\begin{tabular}{|l|l|}
\hline Tipo/Subtipo & Características \\
\hline NEM 2A & CMT associado à FEO + HPT ou a ambos. \\
\hline NEM 2A(1) & CMT, FEO e HPT \\
\hline NEM 2A(2) & CMT e FEO, excluído o diagnóstico de HPT \\
\hline NEM 2A(3) & CMT e HPT, excluído o diagnóstico de FEO \\
\hline NEM 2B & $\begin{array}{l}\text { CMT +/- FEO + anormalidades fenotípicas, geralmente sem HPT } \\
+ \text { ganglioneuromatose }\end{array}$ \\
\hline CMT-F & $\begin{array}{l}\text { CMT em pelo menos 4-10 membros da família, excluídos os } \\
\text { diagnósticos de FEO e HPT no afetado ou em membros sob risco }\end{array}$ \\
\hline Outros & $\begin{array}{l}\text { Famílias com menos de 4 membros com CMT; nenhuma } \\
\text { evidência objetiva de FEO ou HPT ou famílias com diagnóstico } \\
\text { histopatológico não confirmado. }\end{array}$ \\
\hline
\end{tabular}

Eng, 1995

\subsubsection{Carcinoma medular de tireóide associado à NEM2} (CMT/MEN2)

Os carcinomas de tireóide representam cerca de $1 \%$ de todos os carcinomas humanos e o CMT corresponde a cerca de $10 \%-30 \%$ dos tumores malignos da tireóide. Ao redor de $70 \%$ dos CMTs são esporádicos enquanto que 30\% apresentam a forma hereditária (Hoff AO, 2000; Gimm O, 2001; de Groot et al, 2006).

Apresenta prevalência aproximada de 1:30.000, havendo forte concentração de afetados intra-familiarmente. O CMT é evento monoclonal, 
aleatório, multicêntrico e bilateral que tem origem nas células $C$ da tireóide, produtoras de calcitonina. Dessa forma, a calcitonina é o principal marcador bioquímico tumoral dessa doença. $\mathrm{A}$ hiperplasia de células $\mathrm{C}$ corresponde à fase pré-maligna do CMT hereditário, enquanto a forma não-herdada de CMT freqüentemente, mas não obrigatoriamente, não apresenta hiperplasia (Hoff AO, 2000).

As diferenças entre as formas herdadas e não-herdadas do CMT estão sumarizadas no quadro abaixo.

Quadro 3: Diferenças entre as formas herdada e esporádica de CMT

\begin{tabular}{|c|c|c|}
\hline \multicolumn{2}{|c|}{ CMT / NEM2 } & Esporádico \\
\hline Localização & Multicêntrico & Focal \\
\hline Hiperplasia de células C (fase pré - maligna) & + & - \\
\hline Idade ( anos ) & $<30$ & 50 \\
\hline Diagnóstico laboratorial & Mutação RET & Calcitonina elevada \\
\hline Tumores Associados & + & - \\
\hline História familiar & + & - \\
\hline Cirurgia preventiva & + & Paliativo \\
\hline Tratamento & Curativo & + \\
\hline Resistência a radio, quimio, iodo terapias & + & \\
\hline
\end{tabular}

\section{a) Diagnóstico clínico}

O diagnóstico clínico de CMT é usualmente feito diante a nódulo tireoideano associado a níveis elevados de calcitonina sérica; citologia com imunocitoquímica positiva para calcitonina de material de biópsia que seja 
compatível com CMT; achados de biópsia de congelação compatíveis com este tumor; ultra-sonografia de tiróide mostrando nódulo(s) com características neoplásicas. (Ezabella MCL, 1996; Santos MA, 2006; Toledo SPA, 2006).

Entretanto, a hipercalcitoninemia per se não é diagnóstico de CMT, havendo a necessidade de se excluir outras doenças que também podem elevar a calcitonina (Hayashida CY, 1993; Borget I, 2007).

\section{b) Tratamento}

O CMT é um tumor resistente à químio-, rádio-, e iodo terapias (Toledo SPA, 1992). Novas drogas bloqueadoras da ação tirosinaquinase da proteina RET têm sido testadas, entretanto os resultados de tais terapias ainda estão em fase de análise (You YN, 2006).

Atualmente, a cirurgia da tireóide constitui a única abordagem terapêutica realmente eficiente no combate ao CMT. Para os pacientes que já tenham diagnóstico de CMT, o objetivo do tratamento é buscar remover o tumor em seus estágios iniciais, evitando a ocorrência de metástases. Recomenda-se que a cirurgia do CMT seja realizada por especialista com alto treinamento na área (Wells SA Jr, 2000; Tavares MR, 2005).

Além disto, há recomendação dos Consensos internacionais sobre NEMs que a grande maioria dos casos portadores de mutação RET seja submetida à tireoidectomia total preventiva antes dos 4 - 5 anos de idade (Niccoli-Sire P, 1999; Kahraman T, 2002; Skinner MA, 2005; You YN, 2006; Kloos et al, 2009).

A boa tolerância das crianças portadoras de mutações no gene RET à cirurgia e ausência de resultados falso-positivos no diagnóstico molecular do 
RET, foram pontos importantes para os Consensos deliberarem sobre essas recomendações. A tireoidectomia total preventiva tem-se mostrado bastante efetiva e atualmente é a melhor alternativa na prevenção e mesmo cura do CMT (Brandi ML, 2001), visto que o seguimento pós-cirúrgico por cinco (05) anos ou mais, tem revelado a ausência de doença em pacientes operados em baixas idades (em geral, <5 anos) (Brandi ML, 2001; Skinner MA, 2005).

Desde modo, o diagnóstico molecular do RET tem papel fundamental na conduta clínica e no tratamento cirúrgico de pacientes com NEM-2. A implementação deste diagnóstico tem promovido um nítido aumento da sobrevida e melhora da qualidade de vida de pacientes com predisposição genética ao CMT/NEM2 diagnosticados e operados precocemente (Brandi ML, 2001; Figura 1).

Na atual era da genômica, o clínico deve buscar ter acesso à análise de mutação RET, para guiá-lo na abordagem de casos com CMT/NEM-2 e de seus familiares sob-risco.
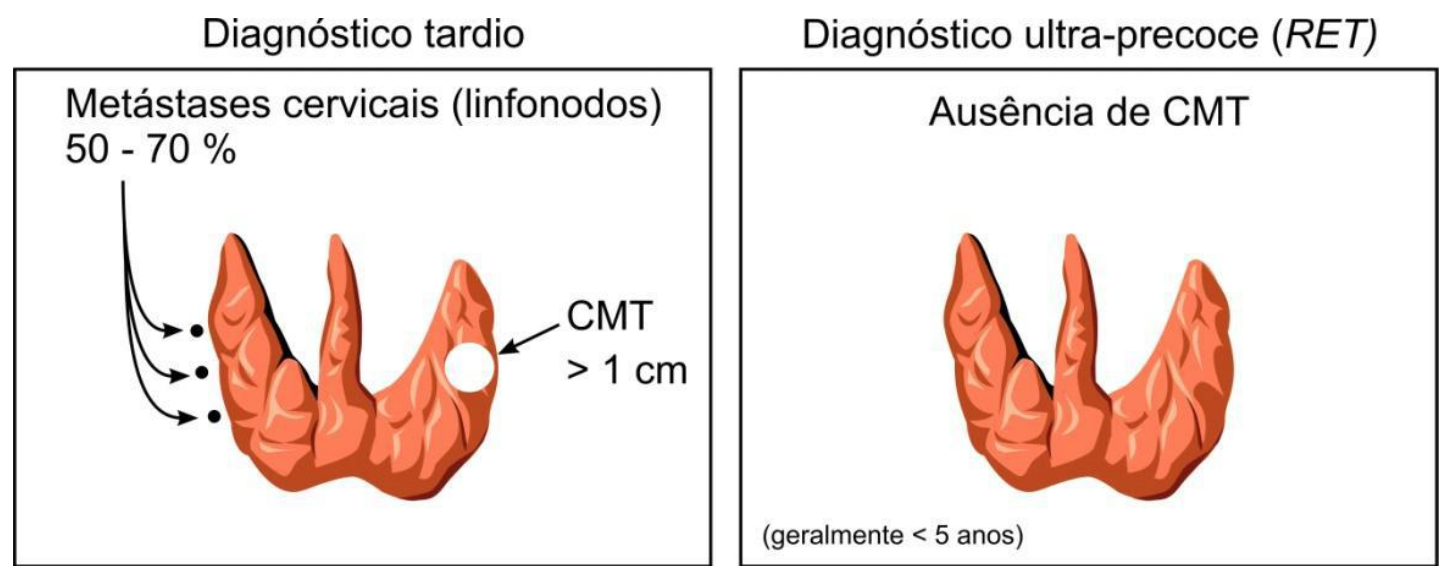

Figura 1: O diagnóstico molecular do RET tem papel fundamental na conduta clínica e no tratamento cirúrgico de pacientes com NEM-2 
Ao ser identificada uma mutação RET em familiares de casos com CMT, com idades abaixo de cinco (05) anos, recomenda-se a realização précirúrgica de dosagem de calcitonina, além de exames de tomografia computadorizada e ultra-som cervicais, para documentação do caso. Em familiares genicamente afetados e com mais de cinco (05) anos de idade, recomenda-se também a realização de tomografia computadorizada de mediastino.

\subsubsection{Feocromocitoma}

O FEO associado à NEM-2 (FEO/NEM-2) possui penetrância de 40 $50 \%$, são benignos em cerca de $90 \%$ dos casos e representam cerca de 10 $\%$ dos FEOs em geral.

O FEO/NEM2 se localiza preferencialmente nas adrenais e são bilaterais em $50-60 \%$ dos casos. Portanto, há necessidade de investigação rotineira e sistemática de possível surgimento de FEO controlateral (60 \% de risco desta ocorrência), uma vez que pode haver assincronia.

O surgimento do FEO/NEM2 pode ocorrer sincronicamente (20-30\%), posteriormente (40-50\%) ou mesmo anteceder o CMT (30\% dos casos) (Brandi ML, 2001). O diagnóstico clínico do FEO/NEM2 segue os mesmos critérios utilizados em relação ao FEO esporádico. As principais diferenças entre o Feo esporádico e o FEO/NEM2 estão relacionadas abaixo. 
Quadro 4: Diferenças entre FEO/NEM-2 e FEO esporádico

\begin{tabular}{|c|c|c|}
\hline \multicolumn{2}{|c|}{ FEO / NEM2 } & FEO esporádico \\
\hline Mutação Gamética RET & + & - \\
\hline Localização & $\begin{array}{c}\text { Bilateral (Assincrônico ) } \\
\text { Multicêntrico }\end{array}$ & $\begin{array}{c}\text { Unilateral, } \\
\text { Solitário }\end{array}$ \\
\hline Fase Hiperplásica & + & - \\
\hline Idade ( anos ) & $<30$ & 50 \\
\hline Tumores Associados & + & - \\
\hline História Familiar & + & - \\
\hline
\end{tabular}

O FEO deve ser ativamente investigado em casos com mutações RET nos códons: 609, 611, 618, 620, 630, 634, 790, 804, 883, 918 e 922 . O tratamento do FEO/NEM2, assim como dos FEO esporádicos, é essencialmente cirúrgico. Na NEM2, a cirurgia do FEO deve sempre preceder à ressecção do $\mathrm{CMT}$, a fim de se evitar a ocorrência de crises adrenérgicas no peri- ou intra-cirúrgico do CMT.

\subsubsection{Hiperparatireoidismo}

O HPT primário associado à NEM-2 caracteriza-se por apresentar hiperplasia multiglandular em $70-80 \%$ dos casos e adenoma no restante; evolução usualmente lenta e suave, tornando-se às vezes de difícil reconhecimento (de Groot et al, 2006). 


\subsubsection{Outros Fenótipos}

Além do CMT, FEO e HPT primário, podem ocorrer outros quadros clínicos na NEM2, como relatado a seguir.

\section{a) Neuromas de mucosa}

Diante do achado de neuromas de mucosas labial, bucal, palpebral, ocular, nasal ou gastrintestinal em crianças de baixa idade, deve-se pensar na possibilidade de NEM2B e obrigatoriamente realizar a análise de mutação do gene RET (Figura 2).

A evolução do CMT no MEN2B é altamente agressiva e precoce, com surgimento freqüentemente antes dos 12 meses de idade.

A NEM2B corresponde a $5 \%$ dos casos de NEM2 e os pacientes podem também apresentar fenótipo marfanóide (75 \%), ganglioneuromatose de intestino ( $40 \%$ ) e FEO (50 \%), enquanto o HPT é extremamente raro (Hoff AO, 2000).

\section{b) Líquen cutâneo amiloidótico}

Raros pacientes com NEM2 e mutação no códon 634 podem apresentar líquen cutâneo amiloidótico em regiões interescapulares (Hoff AO, 2000).

\section{c) Megacólon congênito}

Raramente, o megacólon congênito também pode estar associado à NEM2, usualmente em casos com mutações RET nos códons 609, 618 e 
620 (Brandi ML, 2001). Este tema será detalhado mais adiante, uma vez que faz parte do foco do meu projeto.

\subsubsection{Aspectos moleculares do RET}

\section{a) Mutações no Gene RET}

O proto-oncogene RET (genelD: 5979, NCBI) foi mapeado na região cromossômica 10q11.2 e é composto por 60 Kilobases. O gene RET possui 21 éxons que codificam um receptor transmembrana do tipo tirosinaquinase, a proteina RET.

Em 1993, foram identificadas as primeiras mutações germinativas no proto-oncogene RET em pacientes com NEM-2 (Donnis-Keller H, 1993). A grande maioria de mutações identificadas no RET é pontual, com alteração de um único nucleotídeo que causa a troca de um aminoácido.

Cerca de $95 \%$ dos casos com NEM2 possuem mutação RET, sendo aproximadamente $85 \%$ delas localizadas nos éxons 10 e 11 . O restante das mutações é localizado nos éxons 13, 14, 15 e 16.

Atualmente, sabe-se que aproximadamente $10-30 \%$ dos casos com FEO e $5 \%$ dos casos com CMT, considerados inicialmente como esporádicos, também apresentam mutação germinativa nos éxons hot-spots do gene RET, tratando-se assim de casos hereditários de CMT e FEO até então não diagnosticados.

Casos esporádicos com CMT podem apresentar mutação somática (só no tecido tumoral) no gene RET; entretanto, apesar da identificação 
dessa mutação gerar dados referentes à tumorigênese tireoideana, ela não é informativa para o diagnóstico gênico familiar.

Nos casos com NEM2/CMT familial aparentemente sem mutação nos éxons hot- spots, é recomendado que a análise de mutação seja expandida para o gene RET inteiro, ou seja, os 21 éxons (Longuini VC, 2007) iniciandose pelo éxon 8 (Silva AMA, 2003). Outra característica interessante sobre a genética da NEM2, que será especificada mais adiante nesse capítulo, é sua forte correlação genótipo RET vs. manifestação clínica.

\section{b) Função}

O receptor tirosinaquinase RET possui três domínios protéicos: extracelular, transmembrana e intracelular.

Em situação fisiológica, o domínio extracelular é responsável pela interação com 2 grupos de ligantes ativadores: a) 4 proteínas da família do fator de crescimento e diferenciação neural, GNDF (nerturina, artemina, persepina e o próprio GNDF) e b) 4 co-receptores dos GNDFs, tipo GFRa1-4.

Posteriormente, há formação de um heterotetrâmero que desencadeia uma série de fosforilações nos resíduos intracelulares do RET. Conseqüentemente, três principais vias metabólicas poderão ser ativadas: MAPK, fosfolipase C e JNK (Hoff AO, 2000). Isto leva à proliferação e à diferenciação celular controladas, principalmente de células neuronais.

Em situações patológicas (causadas por mutações ativadoras RET), a estrutura dos receptores RET é alterada e os genes encontram-se constitutivamente ativados, independentemente da presença ou ausência 
dos ligantes. Assim, existe um descontrole e super-ativação dessas vias, levando a um crescimento neoplásico (Marx SJ, 2005).

Alternativamente, mutações inativadoras no $R E T$ podem ser do tipo tecido-dependente (tubo intestinal) e levar ao quadro do HSCR (Edery et al, 1994; Moore et al, 2008).

\section{c) Correlação genótipo-fenótipo}

- NEM-2A

Corresponde a aproximadamente $75 \%$ do total de casos com NEM2. Nela, o CMT está presente em virtualmente 100\% dos casos; o FEO em 50\%; e o HPT em cerca de $20-30 \%$ dos pacientes.

A média da idade ao diagnóstico do CMT/NEM2 na fase prégenômica era de 20-40 anos, tendo havido na fase pós-genômica forte tendência para diminuição da idade ao diagnóstico (Santos MA, 2006; Toledo SPA, 2006).

A maioria dos pacientes com NEM2A apresenta mutações do tipo missense nos éxons 10 e 11 (códons 609, 611, 618, 620, 630, 634). Em algumas populações, o códon 634 corresponde a até $85 \%$ das mutações encontradas, das quais 52\% correspondem à mutação Cys634Arg e 26\% à mutação Cys634Tyr.

Em famílias com elevada incidência de HPT e ausência de Feo, foi descrita duplicação de 12 pb entre os códons 634 e 635 que segrega em associação com a mutação Cys634Arg. 
Mutações germinativas no códon 804 são raramente associadas à NEM2A e ocorrem freqüentemente no CMTF. Em pacientes com esta mutação, o CMT freqüentemente (mas não sempre) tem surgimento tardio, curso mais lento e menos agressivo, provavelmente devido à transformação neoplásica incompleta induzida por esta mutação.

Apesar disto, estes pacientes com mutação RET 804 devem ser seguidos e operados antes dos 10 anos de idade (Feldman GL, 2000; Brandi ML, 2001; Brandi et al, 2001; Kloos et al, 2009).

\section{- CMT-F}

O CMT familiar (CMTF) compreende $20 \%$ dos casos com NEM-2, caracteriza-se pela presença de CMT e ausência de quaisquer achados clínicos e laboratoriais de FEO e HPT no caso-índice, assim como em seus familiares afetados. Dentre os casos de CMTF, $85 \%$ apresentam mutações no proto-oncogene RET, sendo usualmente relacionadas aos éxons 10 e 11.

A mutação Cys618Ser ocorre em $33 \%$ dos casos com CMT-F, seguida da mutação Cys634Tyr (30\%). Raramente encontra-se associação da mutação Cys634Arg com fenótipo CMT-F (Brandi ML, 2001).

Mutações nos códons 609, 611 e 620, assim como nos códons 768 e 804 estão usualmente associadas ao CMT-F, apesar de eventualmente ocorrerem na NEM-2A. 
Mutações menos freqüentes como as nos códons 630, 790, 791, 891 e a duplicação de 12 pares de bases entre os códons 634 e 635 foram descritos em famílias com CMT-F, relacionadas a curso menos agressivo do tumor (Hoff AO, 2000).

\section{- NEM2B}

A NEM2B representa cerca de $5 \%$ dos casos com NEM-2. Nesta síndrome o CMT apresenta evolução neoplásica muito precoce $(<1$ ano de idade), altamente agressiva e que causa metástases regionais em idades muito baixas.

Concomitantemente, incidem FEO, habitus marfanóide e neuromas de mucosa (labiais, linguais, palpebrais, e gastro-intestinal;), sendo que a associação com HPT é muito rara. Dada a enorme precocidade e gravidade deste quadro, o Consenso indica tireoidectomia total antes dos 6 meses de idade nos portadores da NEM2B.

A mutação Met918Thr é encontrada na grande maioria destes casos, sendo que 50 \% dos casos resultam de mutações de novo, no alelo paterno. Outras duas mutações, no códon 883 e 922 também foram encontradas em pacientes com NEM2B (de Groot et al, 2006). 


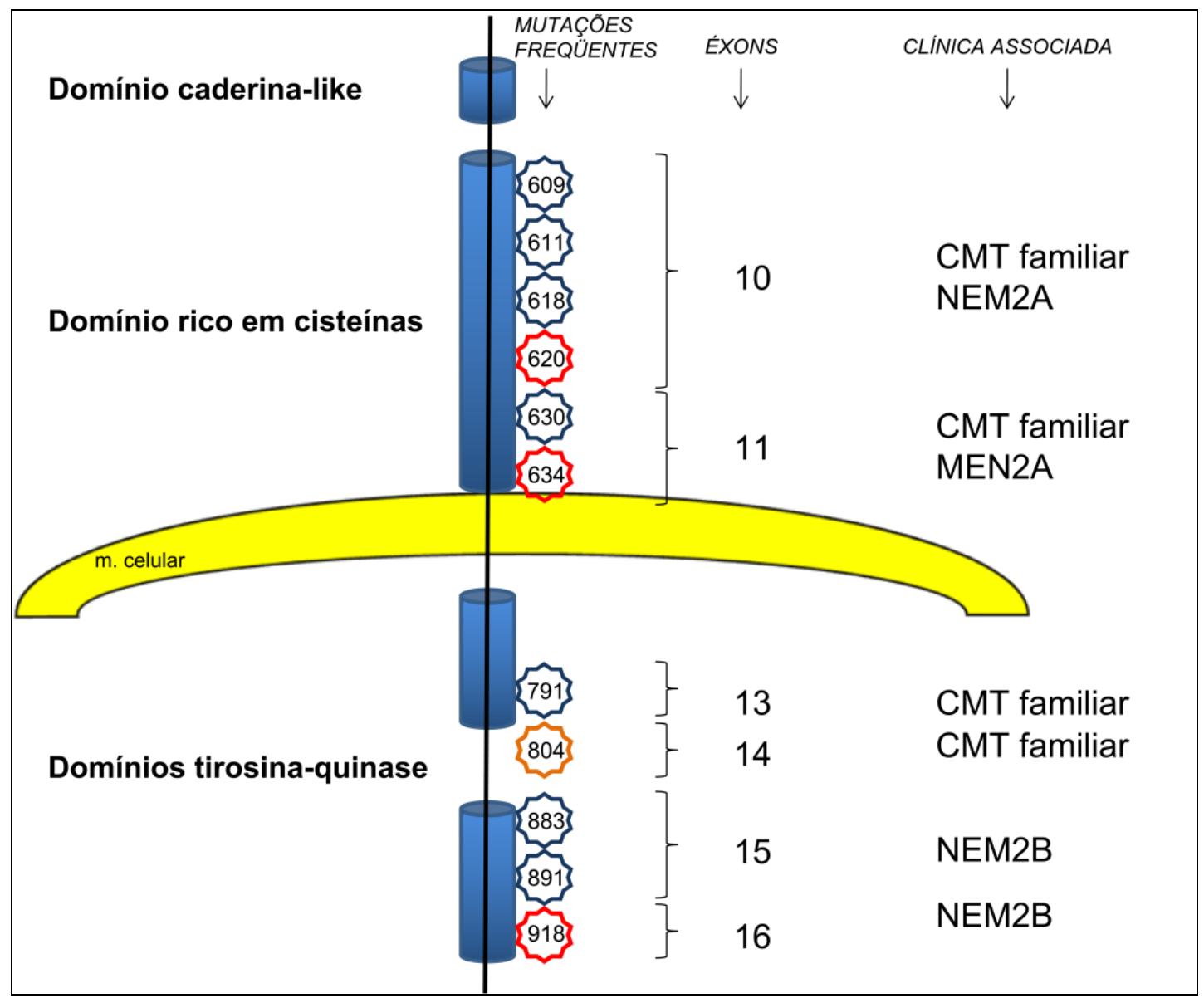

Figura 2: Correlação genótipo-fenótipo na NEM-2

A análise comparativa da agressividade neoplásica e capacidade de transformação neoplásica de mutações relacionadas às diferentes formas de CMT, revelou que o CMT associado à NEM2B é o mais agressivo dos CMTs, seguido pelo CMT associado à NEM2A, pelo CMT associado à CMTF e, finalmente o CMT esporádico (Brandi ML, 2001).

Pelo consenso MENs do NIH (Brandi et al, 2001) há 3 categorias de classificação de risco/gravidade da doença, levando-se em conta exclusivamente as mutações RET. A lista das mutações de cada grupo de risco encontra-se na tabela 5. 
Os casos de altíssimo risco (grau I) devem ser submetidos à tireoidectomia total abaixo dos 6 meses de idade. Os casos de muito alto risco (grau II) devem ser operados antes dos 5 anos de idade.

Os pacientes de alto risco (grau III) devem ser submetidos à ressecção tireoideano completa abaixo dos 10 anos de idade (Brandi ML, 2001). Já o consenso sobre CMT da ATA, considera que há 4 categorias de risco, tendo-se introduzido as mutações no códon 634 como de grau II de risco para CMT, havendo a recomendação para que os portadores destas mutações sejam operados ao redor dos 3 anos (Kloos et al, 2009).

Quadro 5: Classificação/categorias de risco de CMT de acordo com a mutação RET.

\begin{tabular}{|c|c|c|}
\hline Mutação & Grau de risco & Indicação para TT \\
\hline 768 & Alto & $5-10$ anos de idade \\
804 & & \\
891 & & $<5$ anos de idade \\
609 & Muito alto & \\
611 & & \\
618 & & $<6$ meses de idade \\
$634^{*}$ & & \\
\hline 883 & Altíssimo & \\
918 & & \\
922 & & \\
\hline
\end{tabular}

Brandi et al, 2001; * segundo o consenso da ATA, estes casos devem ser operados ao redor dos 3 anos (Kloos et al, 2009). 


\subsubsection{Variabilidade clínica}

Como consta acima, mutações no proto-oncogene RET podem estar associadas a, no mínimo, 4 diferentes fenótipos distintos: a) MEN2A (CMT, HPT, FEO) , b) megacólon congênito, c) MEN2B (CMT, ganglioneuromas, FEO, habitus marfanóide) e d) CMT-F.

A correlação genótipo-fenótipo é bastante forte na NEM2, entretanto muitas dúvidas permanecem relativas à penetrância e a varibilidade fenotípica nestas várias sub-formas da MEN2.

Assim, ainda é impossível se predizer com precisão quais casos individuais, com uma dada mutação RET, poderão apresentar HPT ou FEO e, se for o caso, em que idade apresentariam estes tumores.

Outro exemplo se refere ao raro desenvolvimento de megacólon (agângliose do aparelho intestinal) em alguns portadores de mutação no éxon 10 do gene RET, principalmente no códon 620, mas também nos códons 609 e 618.

\subsubsection{Polimorfismos / Dupla Mutações}

\section{- $\mathrm{CMT} / \mathrm{MEN2}$}

Os estudos sobre SNPs estão sendo atualmente realizados ativamente em relação a diferentes patologias humanas hereditárias ou esporádicas, no intuito de se investigar a potência informativa clínica destes dados. 
Neste contexto, se postula que o estudo dos polimorfismos possa eventualmente trazer novos conhecimentos que poderiam auxiliar no melhor entendimento das variabilidades clinicas encontradas em pacientes com mutação RET.

Recentemente, foi descrita uma associação entre a variante germinativa p.F791Y e o SNP p.L769L em pacientes com CMT-F (S. M. BaumgartnerParzer,).

Vários outros autores têm abordado o potencial papel de fatores genéticos moduladores que poderiam estar presentes em alguns casos de CMT/NEM2, e que tentativamente explicariam a variação do fenótipo nestes pacientes.

Assim, em alguns casos com CMT/NEM2, têm-se descrito a associação de um SNP raro no gene $R E T$ e de uma mutação $R E T$ clássica. Pacientes com estes compostos mutação/SNP podem apresentar fenótipos eventualmente inesperados, tais como o encontro de FEO/NEM2 produtor de ACTH ectópico, levando à doença de Cushing (Mendonça BB, 1988).

Vários outros pacientes com CMT/NEM2 com dupla mutação no RET foram relatados apresentando quadros clínicos inesperados, tais como CMT produtor de calcitonina ou apresentando CMT de evolução relativamente tardia (Bartsch DK, 2000; Tessitore A, 1999).

Em nosso laboratório relatou-se uma família com NEM2A associada à mutação RET clássica p.C634R na qual ocorria, em trans, uma segunda variante genética (SNP) também no éxon 11 do gene RET, pV648I. É muito provável que essa combinação mutação/SNP tenha levado a uma 
modulação fenotípica da MEN2A, pois o paciente desenvolveu um quadro bastante raro de um FEO produtor de $\mathrm{ACTH}$, levando à síndrome de Cushing (Nunes AB, 2002).

Recentemente, descrevemos pacientes com NEM2A apresentando alta penetrância de feocromocitoma e que possuíam, além da mutação clássica p.C634Y, a variante p.F791F em cys (Toledo RA, 2010).

Outros casos têm sido relatados em que um portador comprovado de mutações nos códons intracelulares do RET (691, 790, 791, 904), expressa muito tardiamente o $\mathrm{CMT}$, enquanto que parentes de gerações subseqüentes estariam apresentando CMT de evolução e agressividade mais exacerbada (Brandi ML, 2001).

\section{- HSCR/CMT/MEN2}

Além disto, no nosso laboratório, identificamos uma grande família MEN2 com mutação no códon 620 (p.C620R), sendo que somente poucos casos (5 pacientes) apresentavam associação entre CMT e megacólon congênito, enquanto que o restante dos familiares portadores da mutação (cerca de 23 casos) desenvolveram somente o CMT (Nunes AB, 2002).

Tem-se recentemente aventado a hipótese de que polimorfismos no gene $R E T$ poderiam estar interagindo com a mutação $R E T$ principal, e atuando como fatores moduladores do fenótipo HSCR/MEN2 (Fitze G, 1999; Robledo M, 2003; Menacho IP, 2006; Mendonça BB, 1988; Bugalho MJ, 1994). 
Entretanto, ainda há controvérsias a este respeito (Skinner MA, 2005), havendo também dúvidas quanto à aplicabilidade clínica de achados poliformórficos no $R E T$, que potencialmente poderiam estar influenciando o fenótipo de pacientes portadores dos mesmos.

\subsection{Hirschsprung ou Megacólon congênito}

\subsubsection{Introdução}

A Doença de Hirschsprung (HSCR), ou aganglionose intestinal, é uma doença congênita que apresenta incidência de 1:5000 nascidos vivos, caracterizada pela ausência das células ganglionares nos plexos intermuscular (Auerbach) e submucosos, profundo (Henle) e superficial (Meissner).

Esta lesão é conseqüente a uma falha na migração crânio-caudal das células neuroblásticas vagais da crista neural no intestino distal, durante a embriogenese. O HSCR pode ocorrer sob forma esporádica $(70 \%$ dos casos) ou familiar ( 30\%).

Anomalias cromossômicas podem eventualmente ocorrer em até 12\%

dos casos, sendo a trissomia do Cr. 21 a mais freqüente. Anomalias congênitas associadas ao Hirschsprung podem ocorrer em até $18 \%$ dos casos. Na maioria dos casos o diagnóstico da doença HCSR é clínico, feito no recém-nascido com falha na passagem do mecônio nas primeiras 48 
horas de vida, distensão abdominal que é aliviada por estimulação retal ou enemas, vômitos e enterocolite neonatal.

Análise do DNA por meio de estudos de ligação em famílias com múltiplos indivíduos com HSCR revelaram que múltiplas mutações, em diferentes genes, podem ser a causa dessa enfermidade sindrômica (Edery et al, 1994; Moore et al, 2008).

A mutação mais comumente encontrada (25\%-50\%) em HSCR ocorre no locus do gene RET, 10q11.2, que traduz a proteína transmembrana tirosinaquinase, RET. Por essas características, HSCR tornou-se um modelo de doença de herança complexa, que ainda deve ser melhor elucidado.

\subsubsection{Definição}

A primeira descrição clínica de megacólon congênito foi apresentada à Sociedade de Pediatria de Berlim em 1886 por Harald Hirschsprung. (Hirschsprung H., 1888).

A Doença de Hirschsprung (HSCR), ou aganglionose intestinal, é uma doença congênita relativamente comum, caracterizada pela ausência das células ganglionares nos plexos intermuscular (Auerbach) e submucosos, profundo (Henle) e superficial (Meissner), conseqüente a uma falha na migração da crista neural no intestino distal.

Na maioria dos casos o diagnóstico da doença HCSR é clínico, feito no recém nascido que apresenta manifestações relativas à obstrução intestinal causada pelo aperistaltismo. 


\subsubsection{Epidemiologia}

A incidência da doença de Hirschsprung é de 1:5000 nascidos vivos, sem predileção racial. Entre grupos étnicos, contudo, há significativa variação, com taxas de 1,5, 2,1 e 2,8 por 10.000 nascidos vivos nos caucasianos, afro-americanos e asiáticos, respectivamente (Torfs CP, 1998).

A doença de Hirschsprung de segmento-curto (lesões ganglionares ocorrendo até o sigmóide) é muito mais freqüente que a de segmento-longo (lesões ganglionares ultrapassando cranialmente o sigmóide).

A primeira forma anatômica ocorre em $80 \%$ dos casos com HSCR, enquanto a segunda forma, em $20 \%$. Há predominância pelo sexo masculino numa proporção de 4:1, porém esse índice difere nas duas formas de apresentação: na doença de segmento-curto a relação masculino: feminino é de cerca de 5:1 e na de segmento-longo é de aproximadamente 1:1. (Torfs CP, 1998).

As anomalias congênitas associadas ao Hirschsprung mais freqüentes são: gastrointestinais, fenda palatina, polidactilia, defeitos septais cardíacos e anomalias craniofaciais as mais freqüentes. A ocorrência de anomalias associadas é maior em casos de HSCR familiares, em comparação a casos isolados ( $39 \%$ vs. $21 \%$, respectivamente).

A doença de HSCR pode ocorrer de modo esporádico $(75 \%)$ ou familiar (25\%) (Ederly et al, 1994). Mulligan et al (1994) descreveu pela primeira vez mutações no exon 10 do gene RET associadas a HSCR, em casos com CMT. 
Edery et at (1994) estudando 11 HSCR casos com segmento-curto e 8 com segmento-longo acharam mutações no gene RET tanto em casos HSCR com segmento-longo, como nos com segmento-curto; estes autores concluem que as duas formas anatomicas são expressões de diferenças causadas por sutis variações de expressão das mutações RET no exon 10.

Entretanto, Decker et al, 1998 verifcaram que nos seus casos HSCR/MEN2 a grande maioria dos pacientes apresentava a forma segmento-longo (Decker et al, 1998).

\subsubsection{Apresentação Clínica}

Geralmente a doença de Hirschsprung é diagnosticada em neonatos que se apresentam com obstrução intestinal baixa, com ou sem sepse, associada aos seguintes sinais: falha na passagem do mecônio nas primeiras 48 horas de vida, distensão abdominal que é aliviada por estimulação retal ou enemas, vômitos e, em alguns casos, enterocolite neonatal. Diarréia é sintoma raro (Maksoud, 1998; Rowe MI, 1995).

A HSCR se caracteriza por penetrância baixa ( 20\%) e expressão clínica bastante variável, caracterizada por diferentes graus da ausência de ganglios no tubo intestinal (Fitze et al, 2003).

A extensão de parede intestinal agangliônica tem relação direta com a precocidade da sintomatologia dos pacientes. Logo, quanto mais curto o segmento agangliônico de cólon mais tardios serão os sintomas (Maksoud, 1998). 
Como comentado, a HSCR pode se apresentar sob forma de segmento-curto (80\% dos casos), quando o segmento aganglionico não ultrapassa o limite superior do sigmóide.

Ou como segmento-longo, quando a ausencia de ganglios se extende proximalmente pelo intestino, ultrapassando o sigmóide. Ambas formas anatômicas podem ocorrer na MEN2/HSCR (Edery et al, 1994 Fitze et al, 2003). A ação da proteina tirosinaquinase RET sobre o fenótipo HSCR se dá de maneira dose-dependente, levando a diferentes níveis de agangliose (Fitze et al, 2003).

\subsubsection{Diagnóstico}

$\mathrm{Na}$ maioria dos casos o diagnóstico da doença HCSR é feito no recém nascido com obstrução intestinal que apresenta as seguintes características: falha na passagem do mecônio nas primeiras 48 horas de vida; distensão abdominal que pode ser aliviada por estimulação retal ou enemas; vômitos; e enterocolite neonatal (Amiel J, 2001).

Alguns pacientes são diagnosticados no fim da infância ou na adolescência com constipação severa, distensão abdominal crônica, vômitos, e falha no crescimento. Raramente, pode ocorrer perfuração intestinal.

Os exames realizados para o diagnóstico podem ser: $\mathrm{RX}$ abdominal, manometria ano-retal e exames de imunohistoquimica. Entretanto o exame considerado como padrão-ouro para diagnóstico é a biópsia retal. 


\subsubsection{Mutações, SNPs e HSCR -}

Mutações relativamente raras já foram relatadas em vários genes, levando à HSCR. Assim, já foram descritas mutações nos genes do receptor da endotelina B (EDNRB) e endotelina 3 (EDN3), além de mutações no gene RET.

Dentre estas mutações, as no gene RET são altamente prevalentes, ocorrendo em até $50 \%$ casos familiares de HSCR, e $20 \%$ dos casos esporádicos de HSCR (Attie et al, 1995)

Vários autores têm sugerido que SNPs ou haplótipos podem estar influenciando a expressão da doença de HSCR (Borrego, 2003; Fitze et al, 2003; Moore 2008).

Assim, um SNP no RET foi descrito na Espanha: trata-se de um locus fundador de baixa penetrância, localizado aproximadamente 20-30 bp acima do SNP A45A (Borrego, 2003). Fitze et al (2003) estudaram 7 SNPs intrônicos no gene RET (IVS2+9G>A, IVS4+48A>G, IVS12+47C>T, IVS14-24G>A, IVS19+47T>C, IVS20+96C>T, 3 'UTR+124A>G) em 76 casos de HSCR e concluíram que alguns destes SNPs estavam ligados à presença de HSCR.

Estes autores sugeriram que haplótipos específicos do gene RET podem estar ou gerando ou modificando o fenótipo HSCR. Moore et al (2008) afirmaram que a maioria dos casos com HSCR devem ser causados por variadas possíveis alterações no gene $R E T$, tais como: perda de função, mutações específicas, haplo-insuficiência, SNPs ou haplótipos específicos localizados na região próxima do $R E T$. 
2 Objetivo 
Analisar de forma aprofundada o gene RET para investigar se, em nossos casos com mutação germinativa no gene RET p.C620R, o desenvolvimento do megacólon estaria eventualmente associado à presença de algumas das alternativas: a) uma segunda mutação germinativa; b) um SNP; ou c) a um haplótipo possivelmente funcional ocorrendo neste gene. 
3 Casuística 
Os pacientes com MEN2/CMTF eram pertencentes a uma extensa família com CMTF associada à mutação germinativa RET c.1858T>C (p.C620R).

Dentre estes, 6 familiares apresentaram megacólon congênito. Há relatos que dois outros parentes que faleceram em baixa idade ( $<1$ ano) também apresentavam HSCR (vide genealogia abaixo).

Os 6 casos com HSCR foram operados ou no Nordeste ou no HCFMUSP e apresentavam a forma segmento-longo da HSCR. Seis (06) pacientes desta família com MEN2 e ausência de HSCR foram genicamente analisados quanto a possíveis SNP/haplótipos e os seus dados foram comparados com os seus parentes com CMT/HSCR.

Dados clínicos adicionais desta família já foram parcialmente publicados (Frank-Raue et al, 2010). 


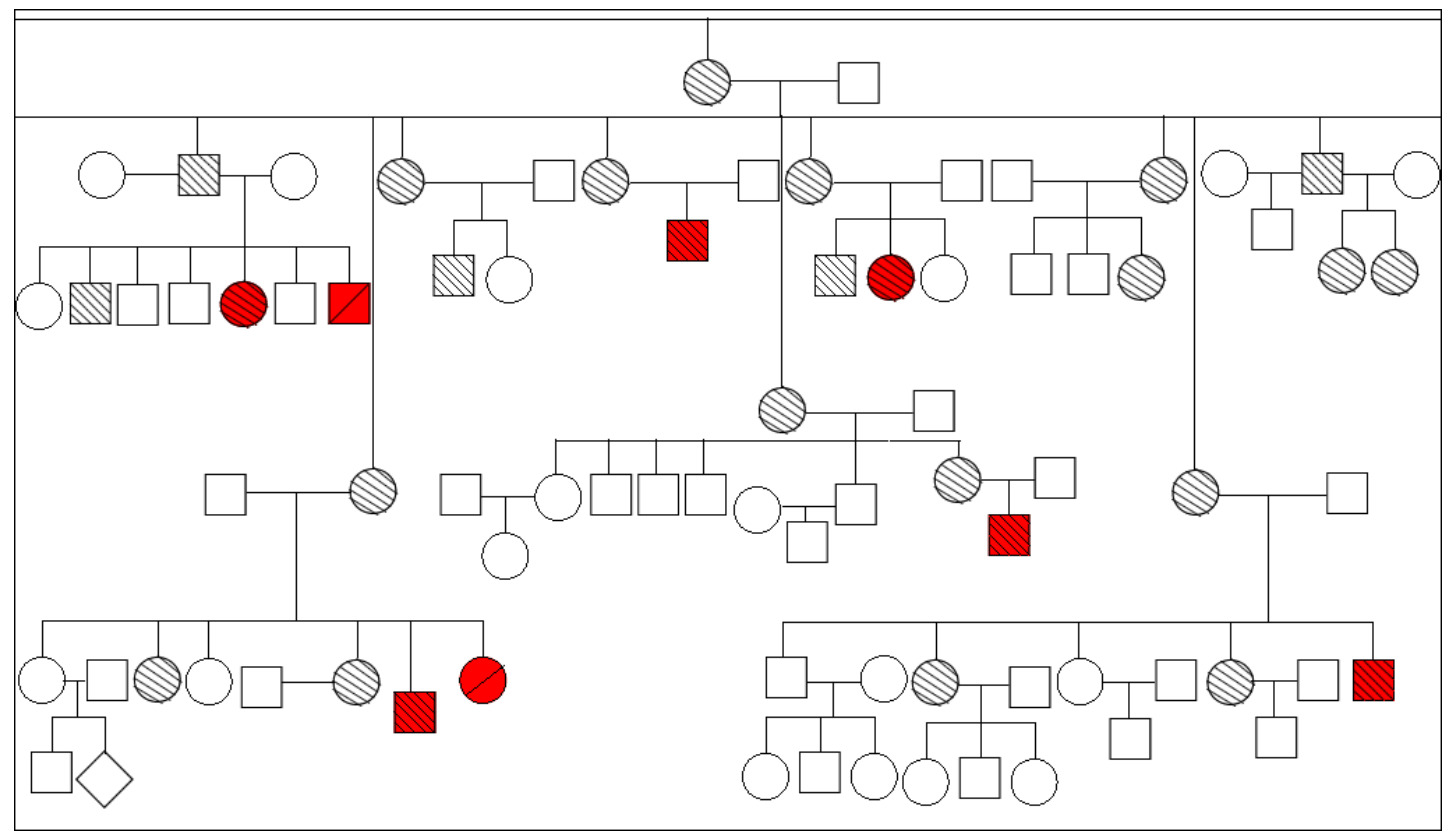

$\checkmark$ pacientes com megacólon falecidos sem material para estudo.

Q 1 pacientes com mutação RET p.C620R sem megacólon.

QN pacientes com mutação RET p.C620R e megacólon.

aproximadamente 35 membros da família afetados com mutação RET p.C620R.

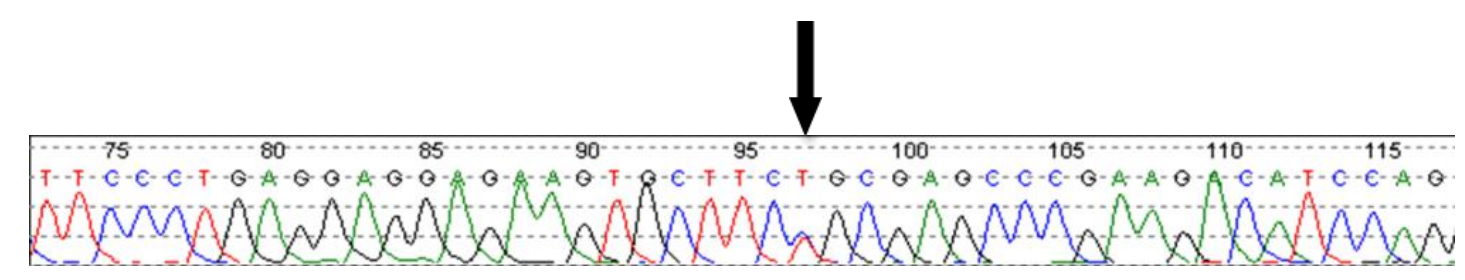

Figura 3: A seta indica a mutação germinativa encontrada na família estudada: uma troca do nucleotídeo T por um C (c.1858T>C, éxon 10), levando a uma troca do aminoácido cisteína por uma arginina 
4 Métodos 
Esta pesquisa foi desenvolvida no Ambulatório de Neoplasia Endócrina Múltipla tipo 1 e 2 (Unidades Ambulatoriais 8000, 8001 e 8002) da Disciplina de Endocrinologia e Metabologia do Hospital das Clínicas da Faculdade de Medicina da Universidade de São Paulo e no Laboratório de Endocrinologia Genética-LIM 25, HC-FMUSP.

O estudo foi aprovado pela Comissão de Ética da Instituição, a Cappesq. Os pacientes ou seus responsáveis assinaram o Termo de Consentimento, após esclarecimento verbal e escrito da pesquisa, concordando com a coleta de material biológico para extração de DNA.

\subsection{Extração de DNA a partir de sangue periférico}

As amostras de DNA de leucócitos de sangue periférico que utilizamos no começo deste trabalho, já se encontravam extraídas e diagnosticadas inicialmente para NEM2.

Para a extração de DNA genômico de células de sangue periférico de trabalhos de campo realizados durante 0 presente projeto foi usado 0 protocolo de extração através do "método Salting Out, mais conhecido como "método do sal" (Ceccherini I, 1994). 


\subsection{Amplificação Gênica por PCR}

Oligonucleotídeos iniciadores, primers, foram desenhados com uso do programa Primer3 (frodo.wi.mit.edu), para análise por PCR e seqüenciamento das seguintes regiões e respectivos polimorfismos: íntron 1 (rs2505533, rs2505532, rs72781232, rs2505531, rs2565206); éxon 2 (rs1800858); íntron 5 (rs1864404); íntron 6 (rs66817951, rs2565205, rs9282835); íntron 7 (rs1864403, rs2251674); éxon 7 (rs1800860); íntron 8 (rs3026750, rs34827976); éxon 11 (rs1799939); éxon 13 (rs1800861); éxon 14 (rs1800862) e éxon 15 (rs1800863).

Além das regiões polimórficas listadas acima, foram desenhados primers para toda a região codificadora do gene $R E T$.

As reações de PCR foram otimizadas nas seguintes condições: 200 ng de DNA genômico, 1,25 U de Taq DNA polimerase, Buffer 1X (200 mmol Tris- $\mathrm{Hcl}$ com pH 8,4 e $500 \mathrm{mmol} / \mathrm{l}$ de $\mathrm{Kcl}$ ) e Mgcl2 1,5 mM (Invitrogen, Brasil); 5\% de sulfóxido dimetil (C2H6SO) - DMSO (Sigma, USA), 10 mM de cada dNTP (Invitrogen, Brasil) e 0,2 $\mu \mathrm{M}$ de cada um dos oligonucleotídeos iniciadores (senso ou antisenso).

A princípio o protocolo já padronizado para estas reações tem uma desnaturação realizada em ciclo único à $94^{\circ} \mathrm{C}$, por 10 minutos (éxons 10,11 , 15 e 16) ou 3 minutos (éxons 13, 14).

Em seguida, 38 ciclos com desnaturação, anelamento e extensão são realizados seguindo as seguintes temperaturas: desnaturação à 94ํㅡ por 30 segundos, anelamento à $60^{\circ} \mathrm{C}$ ou à $62^{\circ} \mathrm{C}$ por 30 segundos e extensão à 
$72^{\circ} \mathrm{C}$ durante 1 minuto. Ao término das ciclagens, todas as reações foram submetidas a ciclo único com extensão final à $72^{\circ} \mathrm{C}$ por 10 minutos.

Os produtos de PCR foram corridos por eletroforese em gel de agarose de $1.5 \%$ e comparados com um marcador de peso molecular de 100pb ladder, para se verificar o tamanho da banda.

\subsection{Purificação do produto de PCR}

Os produtos de PCR foram purificados com o uso da enzima ExoSap (Amersham). Para cada $5 \mu$ do produto de PCR para $2 \mu l$ de ExoSap (Amersham), deixados por 1 hora a $37^{\circ} \mathrm{C}$ (em termociclador) e em seguida a $80^{\circ} \mathrm{C}$ por mais 15 minutos (em termociclador) para denaturação das enzimas.

\subsection{Reação de Seqüenciamento}

Os produtos amplificados via PCR e purificados foram utilizados para o seqüenciamento gênico automático utilizando o kit contendo nucleotídeos Fluorescentes (kit Big Dye Terminator v.3.1, Applied Biosystems, CA, USA), Tampão de seqüenciamento $5 \mathrm{X}$ e um primer.

As reações foram feitas com um volume final de 10ul, contendo 1-3ul de produto de PCR purificado, 1ul de Big Dye, 1ul do primer forward ou reverse (5 pmol/ul), 2 ul de Tampão de seqüenciamento $5 \mathrm{X}$, completando assim o volume final para 10ul com água Milliq. 
As condições de Termociclagem para a reação de seqüenciamento foram:

$1^{\text {a }}$ fase (desnaturação) $-94^{\circ} \mathrm{C}$ por 3 minutos

$2^{\text {a }}$ fase (desnaturação) $-94^{\circ} \mathrm{C}$ por $30 \mathrm{seg}$

$3^{\text {a }}$ fase (anelamento) $-50^{\circ} \mathrm{C}$ por 4 minutos

4aㅡ fase - repetir 29 ciclos, partindo da $2^{\underline{a}}$ até a $3^{\underline{a}}$ fase.

$5^{\text {a }}$ fase $-10^{\circ} \mathrm{C}$ ou $15^{\circ} \mathrm{C}$ (infinito).

\subsection{Protocolo de Precipitação das amostras para Seqüenciamento}

Para cada amostra contendo $10 u$ de reação de seqüenciamento acrescentamos $25 \mu$ l Etanol a 100\% (não gelado),01 $\mu$ l de Acetato de Sódio $3 \mathrm{M}$ e $01 \mu \mathrm{l}$ de EDTA $125 \mathrm{mM}$.

Homogeneizamos a solução no vórtex e após um rápido spin na centrífuga, incubamos por 15 minutos em temperatura ambiente, protegido da luz. Centrifugamos por 45 minutos a $2.169 \mathrm{~g}$ à $4^{\circ} \mathrm{C}$ e em seguida descartamos o sobrenadante.

Acrescentamos a seguir $35 \mu \mathrm{l}$ de etanol a $70 \%$ (não gelado) e centrifugamos novamente à $2169 \mathrm{~g}$ por mais 15 minutos à $4^{\circ} \mathrm{C}$. Após a centrifugação, descartamos o sobrenadante secamos as amostras em banho seco. 


\subsection{Seqüenciamento automático}

As amostras foram seqüenciadas no aparelho Seqüenciador $A B I$ Prism 3130XL (16 capilares), Applied Biosystems, CA, USA. Foram analisados o senso e o anti-senso; todos os seqüenciamentos foram realizados em duplicata.

\subsection{Análise do seqüenciamento}

As análises dos eletroferogramas obtidos foram feitas manualmente através do auxílio de softwares de edição de seqüência.

\subsection{Haplotipagem}

Os haplótipos foram reconstruídos com uso dos programas EHPlus and Hapi (http://linkage.rockefeller.edu).

\subsection{Estatística}

As análises estatísticas realizadas por teste exato de Fisher. 
5 Resultados 


\subsection{Análise da região codificadora do gene RET em pacientes com CMT e megacólon}

Para avaliarmos a presença de uma possível segunda mutação germinativa no gene $R E T$, foram amplificadas e seqüenciadas todas suas regiões codificadoras (21 éxons) de um pool de DNA de dois familiares com a mutação ativadora p.C620R, que desenvolveram megacólon congênito.

Além da mutação ativadora p.C620R, no éxon 10, nenhuma outra variante patogência foi identificada nos éxons codificadores, assim como em suas regiões flanqueadoras desses pacientes. Entretanto, vários polimorfismos encontravam-se em heterozigose.

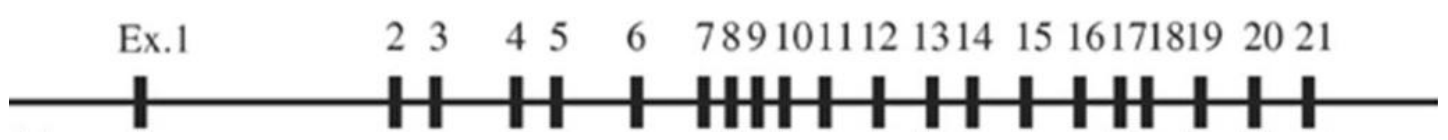

Figura 4: Além da mutação ativadora p.C620R no éxon 10, nenhuma outra variante patogência foi identificada nos éxons 1-20 do gene RET em pacientes com a mutação ativadora p.C620R, que desenvolveram megacólon congênito 


\subsection{Identificação de polimorfismos no gene RET em heterozigose em pacientes com CMT e megacólon}

Durante o seqüenciamento completo do gene RET do pool de pacientes com megacólon, foram encontradas diversas variantes polimórficas em heterozigose. Além dessas variantes identificadas por seqüenciamento, outras variantes foram localizadas no banco de dados de polimorfismos do NCBI.

Inicialmente, esses polimorfismos foram seqüenciados em amostras individuais de cinco familiares com a mutação germinativa p.C620R. Dois deles haviam desenvolvido megacólon, enquanto que os demais não apresentaram lesões intestinais. Esses cinco familiares formam dois ramos da família, compostos um por dois irmãos e o outro por três irmãos. 
Quadro 6: Variantes do gene $R E T$ identificadas em heterozigose em pacientes com mutação p.C620R, com e sem megacólon

\begin{tabular}{|c|c|c|c|}
\hline Polimorfismo & Localização & $\underline{D N A}$ & Proteína \\
\hline rs2505533 & \multirow{6}{*}{ Intron 1} & c. $74-1454 \mathrm{~T}>\mathrm{C}$ & l \\
\hline Novo SNP-1 & & c. $74-1379 \mathrm{~T}>\mathrm{A}$ & / \\
\hline rs2505532 & & c. $74-1362 \mathrm{C}>\mathrm{T}$ & I \\
\hline rs72781232 & & c. $74-1329 G>A$ & I \\
\hline rs2505531 & & c. $74-1290 \mathrm{~T}>\mathrm{C}$ & I \\
\hline rs2565206 & & c. $74-126 \mathrm{G}>\mathrm{T}$ & l \\
\hline rs1800858 & Exon 2 & c. $135 \mathrm{G}>\mathrm{A}$ & p. $A 45 A$ \\
\hline rs1864404 & Intron 5 & c. $1064-89 A>T$ & I \\
\hline Novo SNP-2 & Intron 7 & c. $1522+58 \mathrm{C}>\mathrm{A}$ & l \\
\hline rs1800860 & Exon 7 & c. $1296 \mathrm{~A}>\mathrm{G}$ & p. $A 432 A$ \\
\hline rs3026750 & \multirow{2}{*}{ Intron 8} & c. $1648+84 G>A$ & / \\
\hline rs34827976 & & c. $1648+88$ delC & l \\
\hline rs1799939 & Exon 11 & c. $2071 \mathrm{G}>\mathrm{A}$ & p. G691S \\
\hline rs1800861 & Exon 13 & c. $2307 \mathrm{~T}>\mathrm{A}$ & p. L769L \\
\hline rs1800862 & Exon 14 & c. $2508 \mathrm{C}>\mathrm{T}$ & p. S836S \\
\hline rs1800863 & Exon 15 & c. $2712 \mathrm{C}>\mathrm{G}$ & p. S904S \\
\hline
\end{tabular}

Sequência referência NM_020630.4 


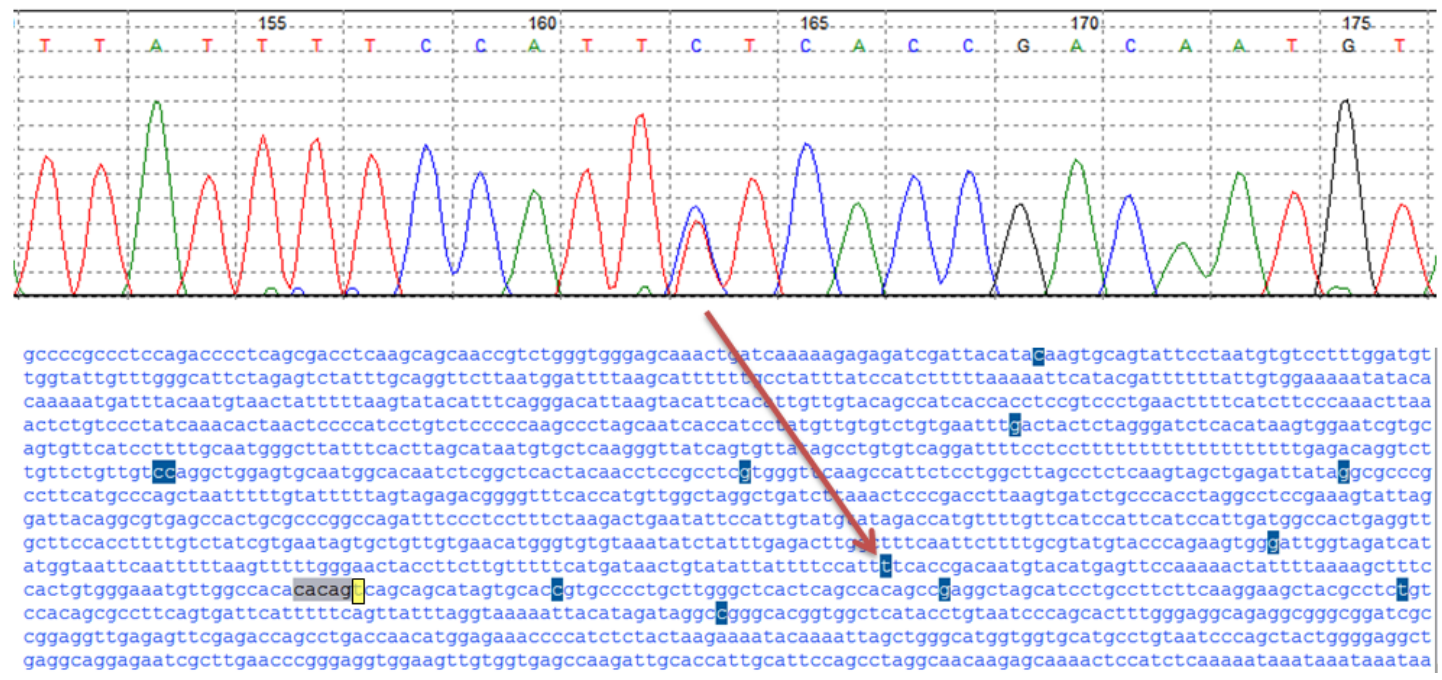

Figura 5: Polimorfismo c.74-1454T>C (rs2505533) no íntron 1 do gene RET

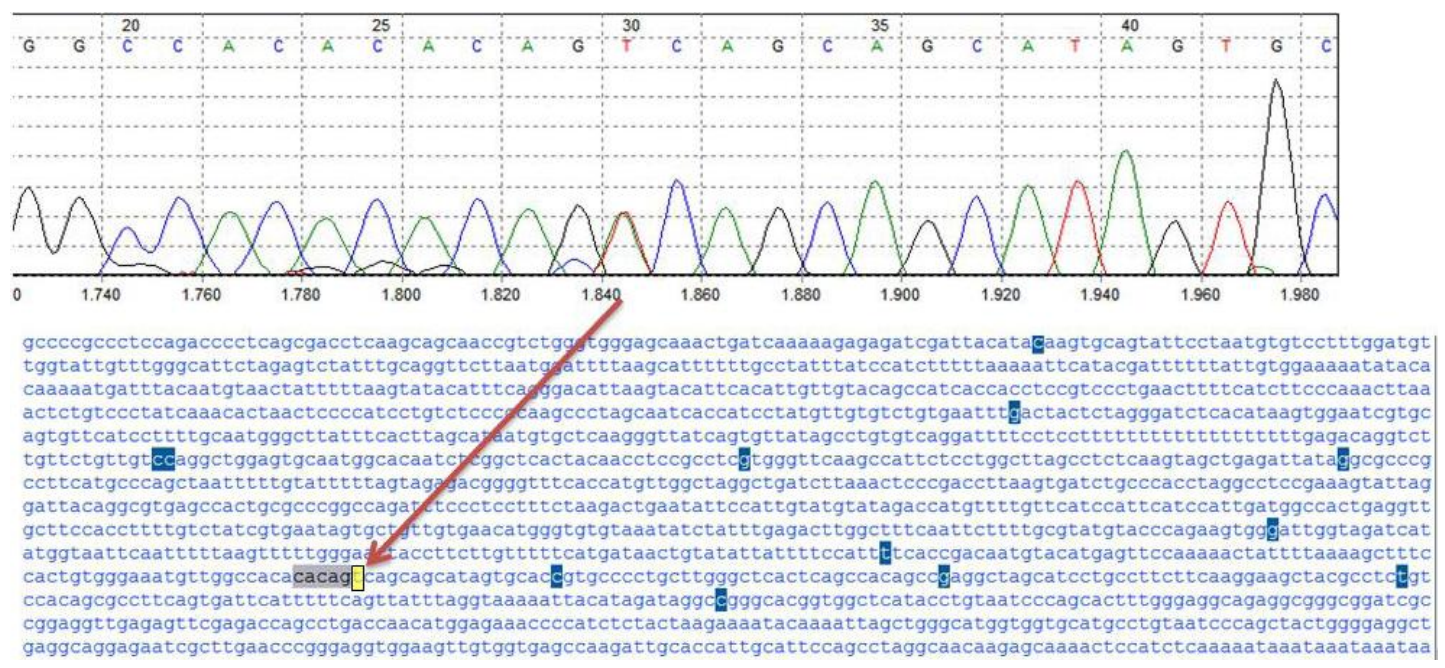

Figura 6: Polimorfismo c.74-1379T>A no íntron 1 do gene RET. Trata-se de uma variante previamente não identificada e que será depositada no banco de dados do NCBI 


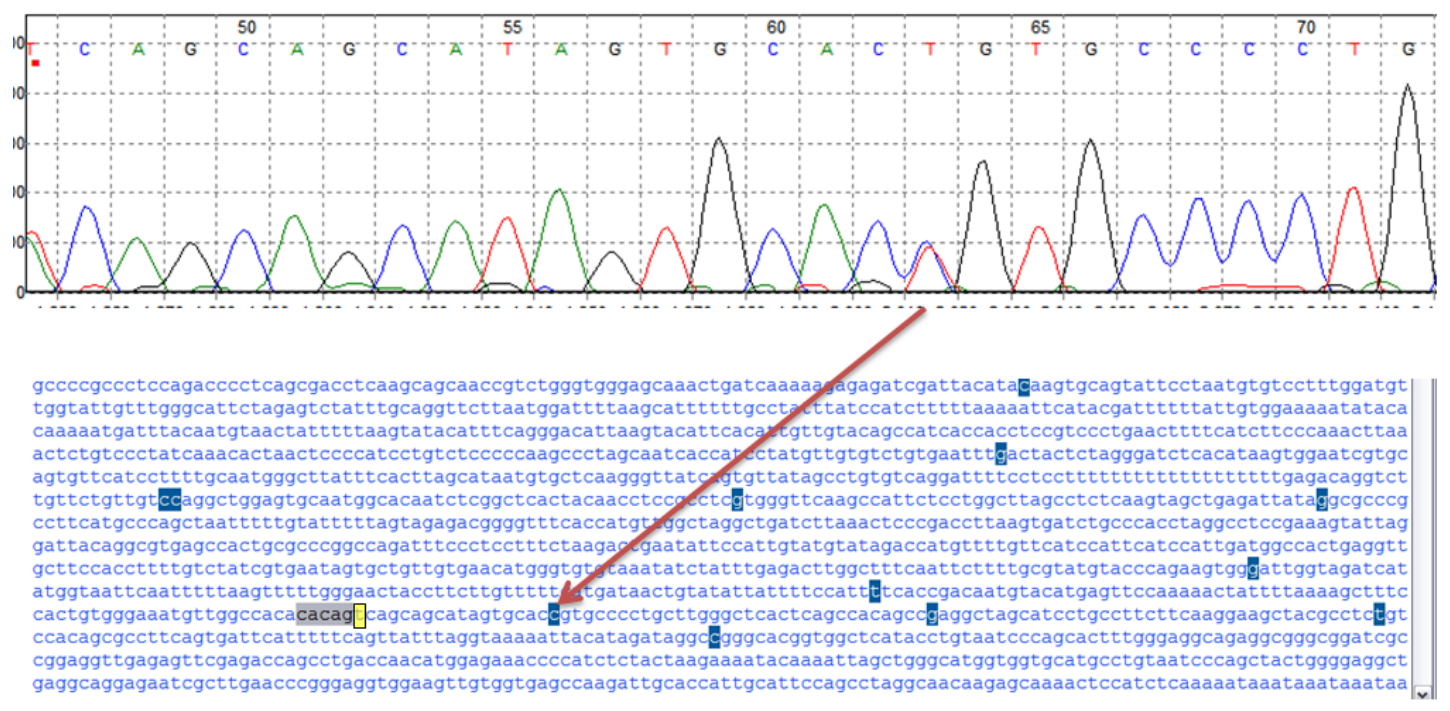

Figura 7: Polimorfismo c.74-1362C >T (rs2505532) no íntron 1 do gene RET

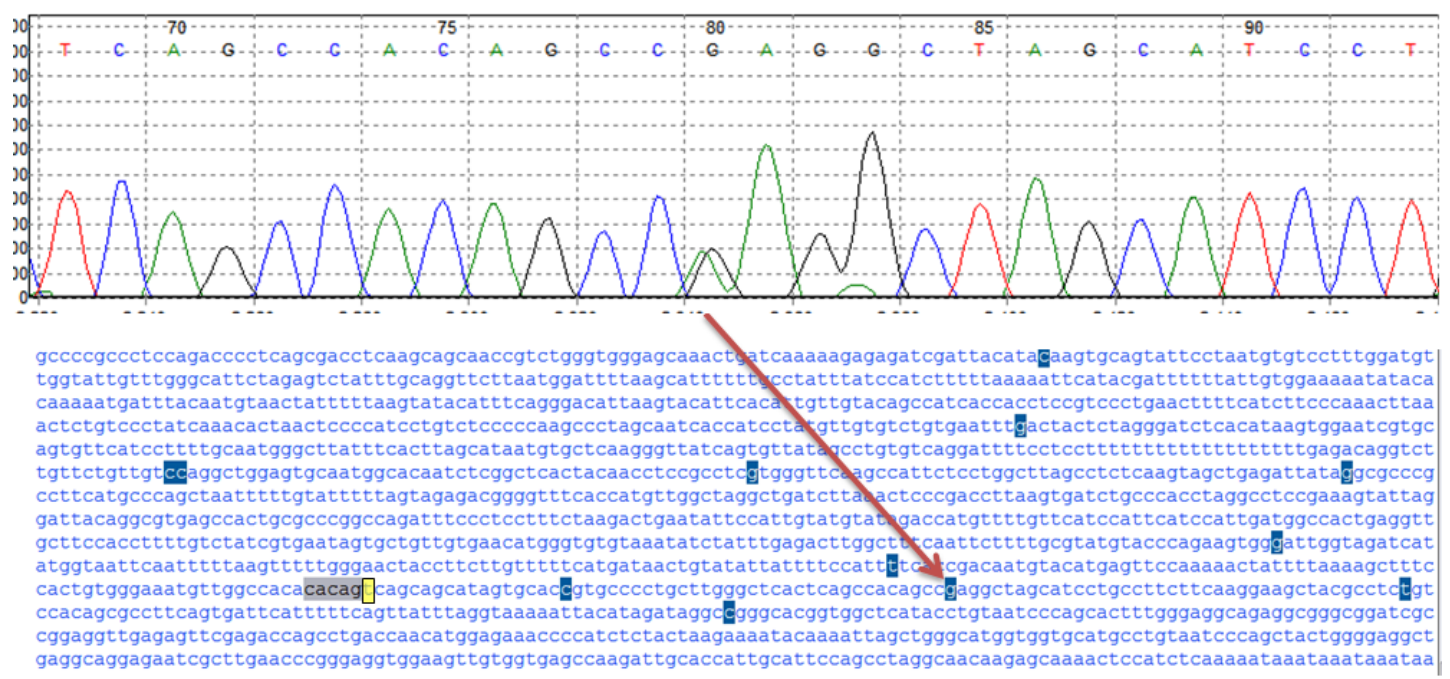

Figura 8: Polimorfismo c.74-1329G>A (rs72781232) no íntron 1 do gene $R E T$ 


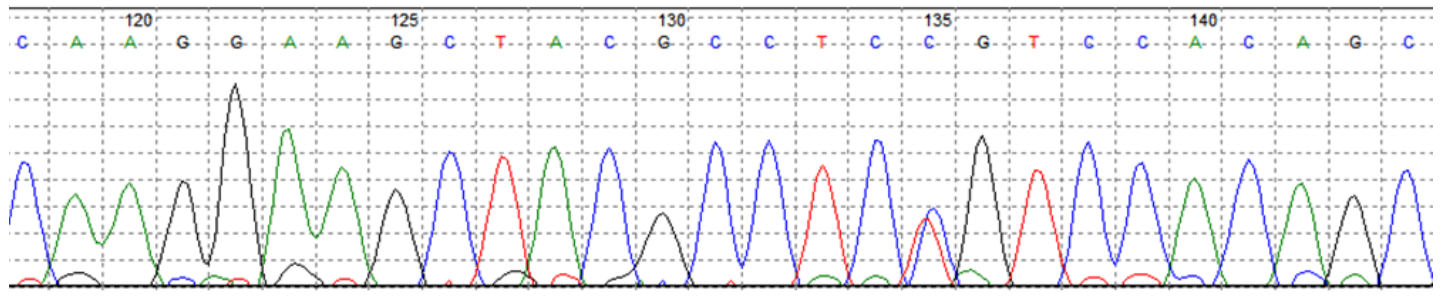

gccccgccctccagacccctcagcgacctcaagcagcaaccgtctgggtgggagcaaactgatcaaaaagagagatcgattada jaagtgcagtattcctaatgtgtcctttggatgt tggtattgtttgggcattctagagtctatttgcaggttcttaatggattttaagcattttttgcctatttatccatctttttaaaan tcatacgattttttattgtggaaaaatataca caaaatgatttacaatgtaactatttttaagtatacatttcagggacattaagtacattcacattgttgtacagccatcaccacctcconcctgaacttttcatcttcccaaacttaa actctgtccctatcaaacactaactccccatcctgtctcccceagccctagcaatcaccatcctatgttgtgtctgtgaatt foctactctarggatctcacataagtggaatcgtgc agtgttcatccttt gca

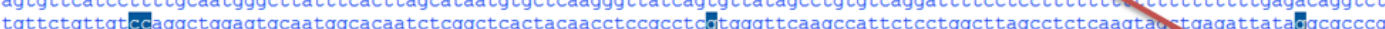

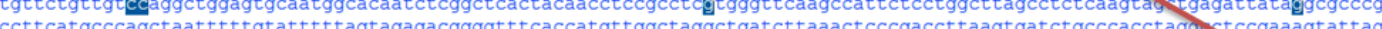
gatceatgotectectagg tecgaaagtattag (1) cactgtggo ccact

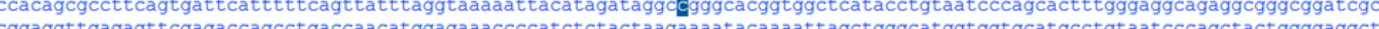
gaggcaggagaatcgettgaacccgggaggtggaagttgtggtgagccaagattgcaacattgcattccagcetaggcaacaagagcaaaactccatctcaaaaataaataaataaataa

Figura 9: Polimorfismo c.74-1290T>C (rs2505531) no íntron 1 do gene $R E T$

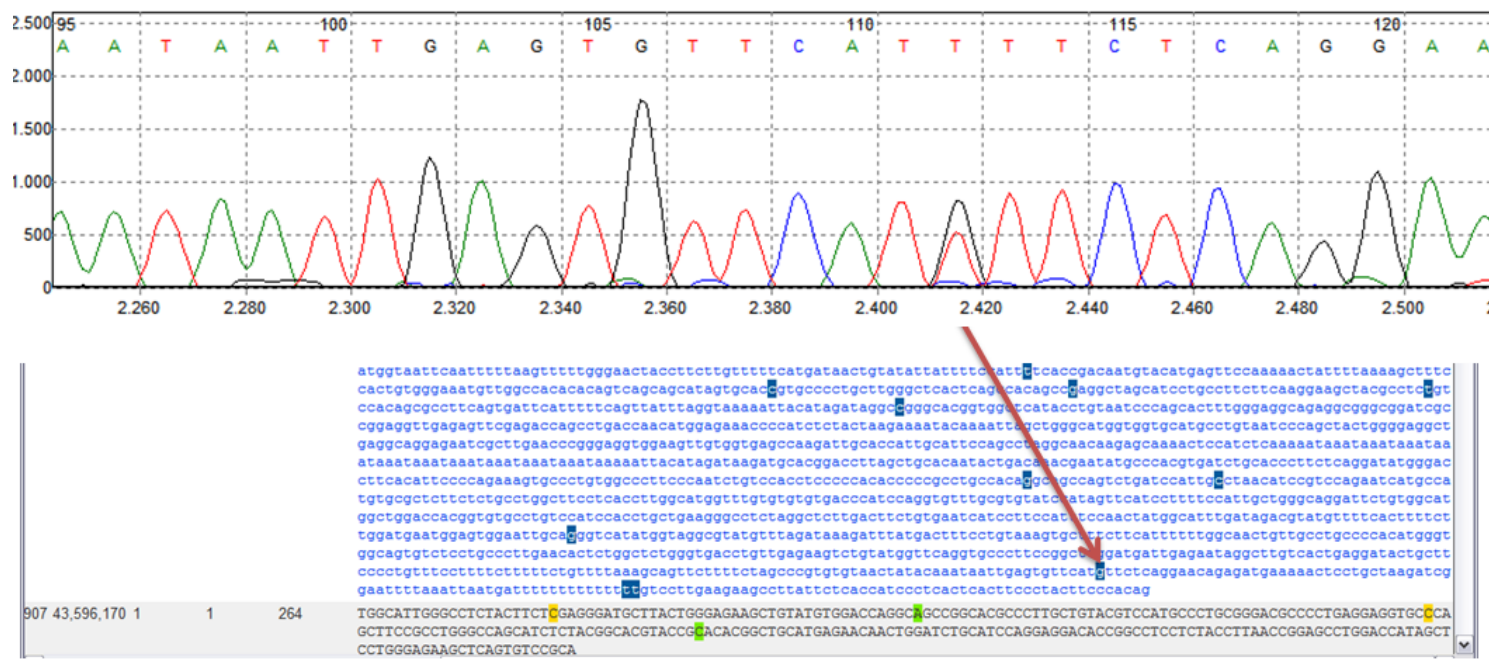

Figura 10: Polimorfismo c.74-126G>T (rs2565206) no íntron 1 do gene RET 


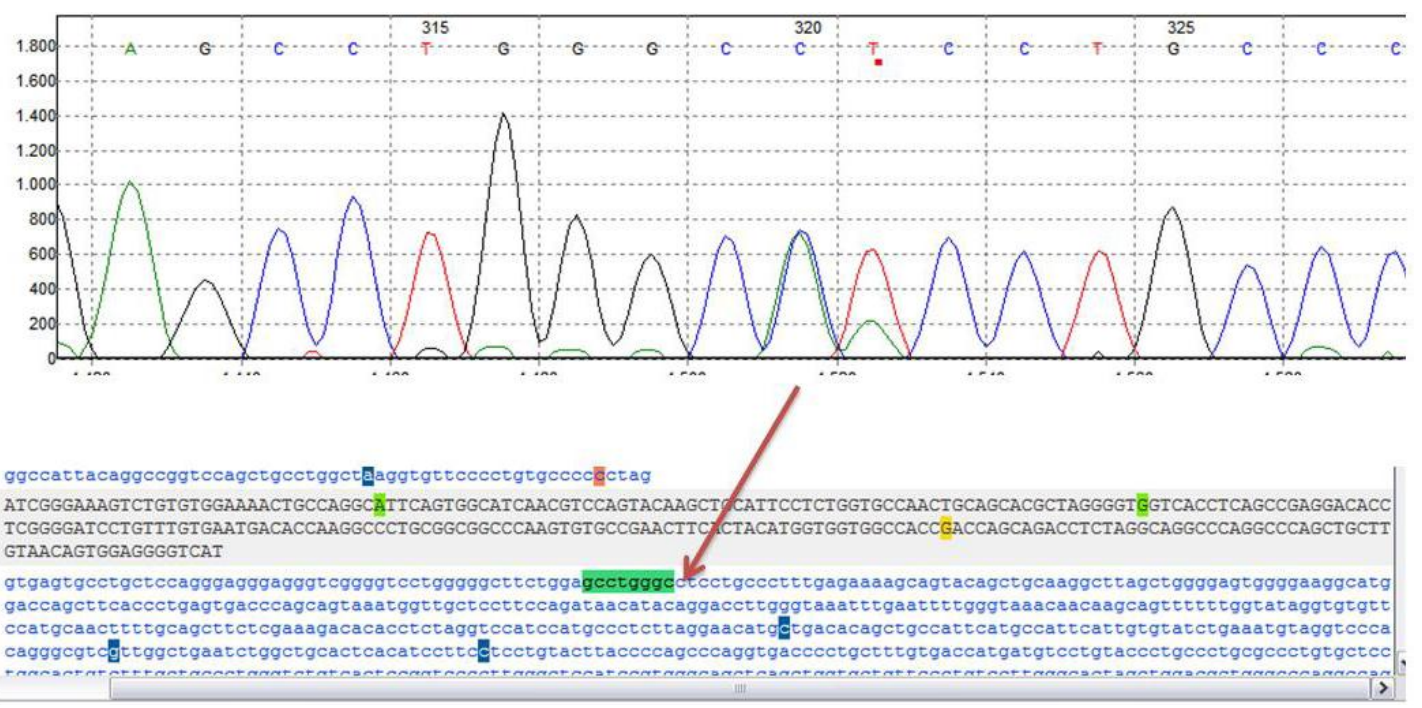

Figura 11: Polimorfismo c. $1522+58 \mathrm{C}>\mathrm{A}$ no íntron 7 do gene $R E T$. Trata-se de uma variante previamente não identificada e que será depositada no banco de dados do NCBI

\subsection{Identificação de haplótipos no gene RET em pacientes com CMT e megacólon}

A identificação de diversos SNPs no gene RET proporcionou a caracterização de alelos que estavam segregando de forma conjunta, haplótipos. Haplótipos incluindo os seguintes polimorfismos foram investigados: rs2505533, novo SNP intron 1, rs2505532, rs72781232, rs2505531, rs2565206, rs1800858, rs1864404, rs1800860, rs3026750, rs34827976, rs1799939, rs1800861 e rs1800863.

Um primeiro haplótipo identificado foi 0 associado à mutação p.C620R. Assim, todos os cinco indivíduos (com e sem megacólon) deveriam compartilhar esse haplótipo. Usando a ordem dos polimorfismos 
acima como referência, os pacientes compartilhavam o seguinte haplótipo: CTCGTGGTGAdel.

\begin{tabular}{|c|c|}
\hline rs2505533 & $\underline{\boldsymbol{C}}$ \\
\hline Novo SNP & $\underline{\boldsymbol{T}}$ \\
\hline rs2505532 & $\underline{\boldsymbol{C}}$ \\
\hline rs72781232 & $\underline{\boldsymbol{G}}$ \\
\hline rs2505531 & $\underline{\boldsymbol{T}}$ \\
\hline rs2565206 & $\underline{\boldsymbol{G}}$ \\
\hline rs1800858 & $\underline{\boldsymbol{G}}$ \\
\hline rs1864404 & $\underline{\boldsymbol{T}}$ \\
\hline rs1800860 & $\underline{\boldsymbol{G}}$ \\
\hline rs3026750 & $\underline{\boldsymbol{A}}$ \\
\hline rs34827976 & $\underline{\boldsymbol{d e l}}$ \\
\hline
\end{tabular}

Figura 12: Haplótipo associado à mutação p.C620R

Excluindo-se de cada polimorfismo estudado o alelo que compõe o haplótipo associado à mutação RET p.C620R, foi observado um outro haplótipo formado em cada paciente. Entre os três irmãos do ramo chamado HSCR-1, pudemos observar que os dois irmãos que não desenvolveram megacólon compartilhavam o haplótipo CATACTGTAAdelATG (Figura 13), enquanto o irmão que desenvolveu megacólon apresentava um haplótipo diferente, o haplótipo TTCGTTAAAGCGGC (Figura 14). 


\begin{tabular}{|c|c|}
\hline rs2505533 & C \\
\hline Novo SNP & A \\
\hline rs2505532 & T \\
\hline rs72781232 & A \\
\hline rs2505531 & C \\
\hline rs2565206 & T \\
\hline rs1800858 & G \\
\hline rs1864404 & T \\
\hline rs1800860 & A \\
\hline rs3026750 & A \\
\hline rs34827976 & del \\
\hline
\end{tabular}

Figura 13: Haplótipo compartilhado pelos 2 irmãos sem megacólon do ramo HSCR-1 da família

\begin{tabular}{|c|c|}
\hline rs2505533 & T \\
\hline Novo SNP & T \\
\hline rs2505532 & C \\
\hline rs72781232 & G \\
\hline rs2505531 & T \\
\hline rs2565206 & T \\
\hline rs1800858 & A \\
\hline rs1864404 & A \\
\hline rs1800860 & A \\
\hline rs3026750 & G \\
\hline rs34827976 & C \\
\hline
\end{tabular}

Figura 14: Haplótipo apresentado pelo irmão com megacólon, do ramo HSCR-1 da família 
Assim como o encontrado no ramo da família HSCR-1, no segundo ramo (HSCR-2), composto por dois irmãos - um que desenvolveu megacólon congênito e outro que não desenvolveu megacólon - pôde-se verificar uma separação dos fenótipos de acordo com os haplótipos.

O haplótipo do irmão com megacólon do ramo HSCR-2 era exatamente o mesmo que o haplótipo do irmão com megacólon do ramo HSCR-1, TTCGTTAAAGC. Já o haplótipo do irmão sem megacólon do ramo HSCR-2 (CATATTGTAAdel) diferiu um pouco do haplótipo encontrado nos irmãos sem megacólon do ramo HSCR-1 (rs1799939, rs1800861, rs1800863.

\subsection{O haplótipo TTCGTTAAAGC co-segrega com o fenótipo de megacólon nos ramos HSCR-1 e HSCR-2 da família com a mutação $R E T$ p.C620R}

Ao incluirmos haplótipos identificados nos familiares dos ramos com megacólon da família (HSCR-1 e HSCR-2) na genealogia, podemos observar uma co-segregação do haplótipo TTCGTTAAAGC com o fenótipo de megacólon. Já os três familiares que não desenvolveram megacólon herdaram outros haplótipos.

Também pode-se observar que somente os familiares com HSCR apresentavam os SNPs: novo SNP-1, rs2505532, rs72781232 e rs2505531 em homozigose. 


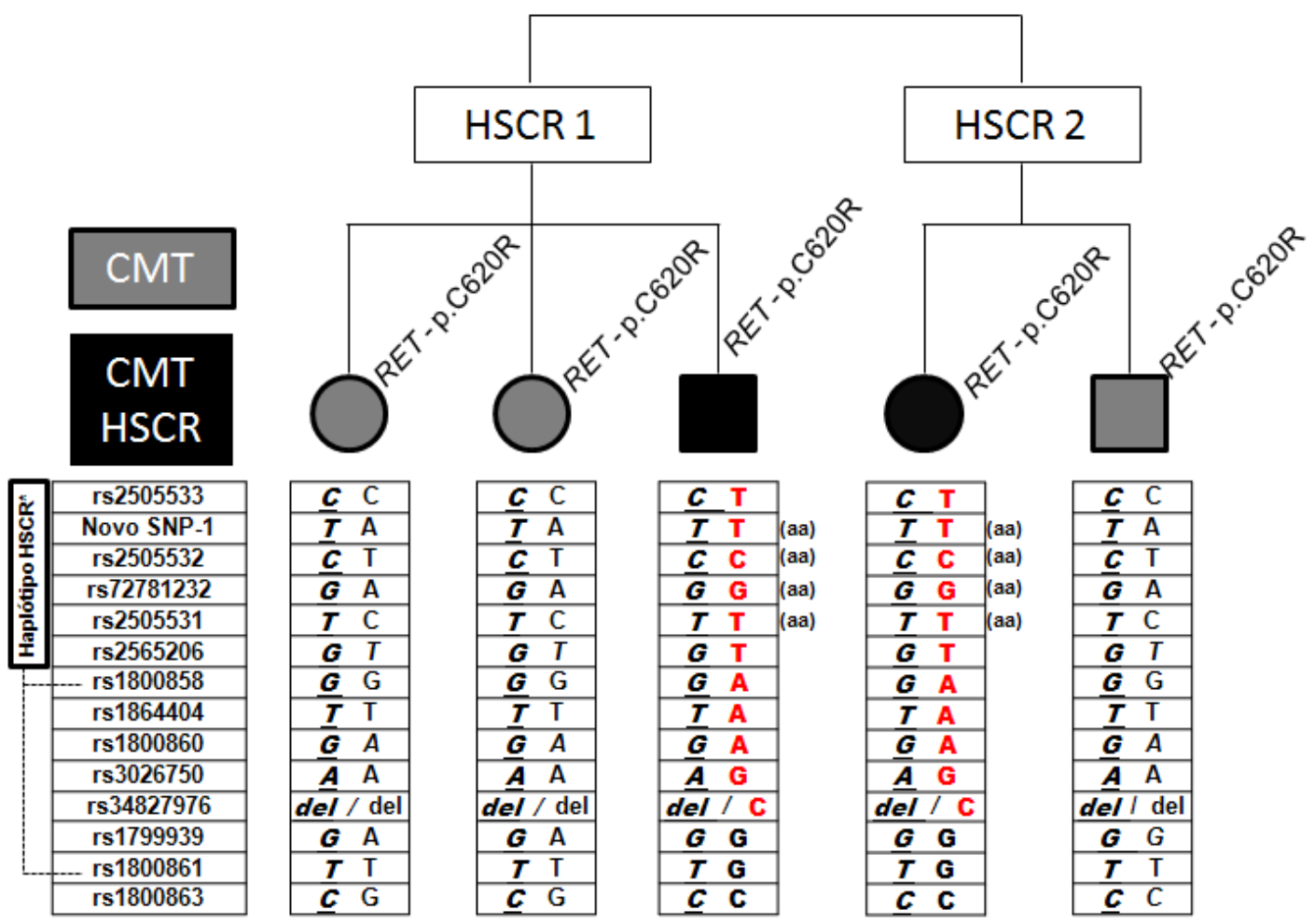

Figura 15: Dados clínicos e genéticos de dois ramos da família com a mutação RET p.C620R e megacólon (HSCR-1 e HSCR-2) são mostrados. Todos os familiares apresentam a mutação germinativa e o haplótipo CTCGTGGTGAdel, mostrado em negrito e itálico, do lado esquerdo. Do lado direito, pode-se observar o haplótipo restante. Os dois irmãos com mega-cólon apresentam o mesmo haplótipo, TTCGTTAAAGC, enquanto que os três que não desenvolveram lesões intestinais apresentam haplótipos diferentes

\subsection{Análise de outros familiares com a mutação RET p.C620R com e sem megacólon para comparação dos haplótipos}

Outros quatro familiares com a mutação RET p.C620R (3 sem HSCR e 1 com HSCR), pertencentes a esta família foram também incluídos no estudo para aprofundarmos a análise haplotípica. Como confirmação de 
nossos dados anteriores, os três familiares sem HSCR apresentavam o haplótipo TTCGTTAAAGC, enquanto o outro familiar com HSCR apresentava o mesmo padrão dos parentes com HSCR. Com esses novos casos, apenas os 3/9 familiares com megacólon apresentavam o haplótipo TTCGTTAAAGC $(p=0.012)$. Ao compararmos os haplótipos dos familiares que não desenvolveram megacólon $(\mathrm{N}=6)$, observamos que todos eles compartilhavam o haplótipo CATGTAdelT, composto pelos seguintes polimorfismos: rs2505533, rs72781232, rs2565206, rs1800858, rs1864404, rs3026750, rs34827976 e rs1800861 (Figura 17).

\begin{tabular}{|c|c|c|c|c|c|c|c|c|}
\hline SNP - ID & Loc. & \begin{tabular}{|c|} 
FAMILIAR 1 \\
N-HSCR
\end{tabular} & $\begin{array}{c}\text { FAMILIAR } 2 \\
\text { N-HSCR }\end{array}$ & $\begin{array}{c}\text { FAMILIAR } 3 \\
\text { N-HSCR }\end{array}$ & $\begin{array}{c}\text { FAMILIAR } 4 \\
\text { N-HSCR }\end{array}$ & $\begin{array}{c}\text { FAMILIAR } 5 \\
\text { N-HSCR }\end{array}$ & \begin{tabular}{|c|} 
FAMILIAR 6 \\
N-HSCR
\end{tabular} & HSCR \\
\hline rs2505533 & c.74-1454T>C & C & C & C & C & C & C & $\mathbf{T}$ \\
\hline Novo SNP & & $\mathbf{A}$ & $\mathbf{T}$ & $\mathbf{T}$ & $\mathbf{T}$ & $\mathbf{T}$ & $\mathbf{A}$ & $\mathbf{T}$ \\
\hline rs2505532 & c.74-1362C>T & $\mathbf{T}$ & $\mathbf{T}$ & $\mathbf{T}$ & $\mathbf{T}$ & $\mathbf{T}$ & C & C \\
\hline rs72781232 & c.74-1329G $>A$ & $\mathbf{A}$ & $\mathbf{A}$ & $\mathbf{A}$ & $\mathbf{A}$ & $\mathbf{A}$ & $\mathbf{A}$ & G \\
\hline rs2505531 & c.74-1290T>C & C & $\mathbf{T}$ & $\mathbf{T}$ & C & C & $\mathbf{T}$ & $\mathbf{T}$ \\
\hline rs2565206 & c.74-126G $>\mathrm{T}$ & $\mathbf{T}$ & $\mathbf{T}$ & $\mathbf{T}$ & $\mathbf{T}$ & $\mathbf{T}$ & $\mathbf{T}$ & $\mathbf{T}$ \\
\hline rs1800858 & $\begin{array}{c}\text { p.A45A } \\
\text { (éxon 2) }\end{array}$ & $\mathbf{G}$ & $\mathbf{G}$ & $\mathbf{G}$ & $\mathbf{G}$ & $\mathbf{G}$ & $\mathbf{G}$ & $\mathbf{A}$ \\
\hline rs1864404 & IVS-5 & $\mathbf{T}$ & $\mathbf{T}$ & $\mathbf{T}$ & $\mathbf{T}$ & $\mathbf{T}$ & $\mathbf{T}$ & $\mathbf{A}$ \\
\hline rs3026750 & IVS-8 & $\mathbf{A}$ & $\mathbf{A}$ & $\mathbf{A}$ & $\mathbf{A}$ & $\mathbf{A}$ & $\mathbf{A}$ & G \\
\hline rs34827976 & IVS-8 & del & del & del & del & del & del & C \\
\hline rs1799939 & $\begin{array}{c}\text { c.2071G>A } \\
\text { (éxon11) }\end{array}$ & $\mathbf{A}$ & $\mathbf{G}$ & $\mathbf{A}$ & $\mathbf{A}$ & $\mathbf{A}$ & $\mathbf{G}$ & G \\
\hline rs1800861 & $\begin{array}{c}\text { c.2307T>A } \\
\text { (éxon 13) }\end{array}$ & $\mathbf{T}$ & $\mathbf{T}$ & $\mathbf{T}$ & $\mathbf{T}$ & $\mathbf{T}$ & $\mathbf{T}$ & G \\
\hline rs1800863 & $\begin{array}{c}\text { c.2712C>G } \\
\text { (éxon 15) }\end{array}$ & G & C & $\mathbf{G}$ & $\mathbf{G}$ & $\mathbf{G}$ & C & c \\
\hline
\end{tabular}

Figura 16: Os haplótipos de seis familiares com mutação RET p.C620R e que não desenvolveram megacólon são mostrados. Nenhum deles apresentava o haplótipo encontrado nos dois irmãos com mutação $R E T$ p.C620R e que desenvolveram megacólon (em vermelho, à direita). Em conjunto, se observa que os marcadores rs2505533, rs72781232, rs2565206, rs1800858, rs1864404, rs3026750, rs34827976 e rs1800861 diferiram entre os familiares com e sem megacólon 
Mutações ativadoras no proto-oncogene RET estão associadas ao desenvolvimento de CMTF, NEM2A e NEM2B dependendo de sua localização, como descrito na Introdução desta dissertação de mestrado (Eng C, 1999; Donnis-Keller H, 1993).

Essas mutações são localizadas em regiões chamadas de hot-spots mutacionais, causam a ativação constitutiva da via da MAPK e levam à tumorigênese tireoideana e da medula da adrenal, assim como das paratireóides (You YN, 2006).

Mutações inativadoras no proto-oncogene RET estão associadas ao desenvolvimento de megacólon congênito e essas mutações geralmente levam à inativação da via da MAPK e/ou baixa expressão do receptor RET (Attie et al, 1994).

Além das mutações inativadoras, foi mostrado que alguns polimorfismos do gene RET têm sua freqüência alélica significativamente aumentada ou reduzida em pacientes com megacólon, em comparação com controles sadios (Fitze G, 1999).

Esses polimorfismos associados ao HSCR foram haplótipos caracterizados por estudos in vitro e, sob o ponto de vista funcional, são compostos por marcadores de baixa penetrância de inativação de sinal, que quando associados atingem um limiar que leva à manifestação da doença. Isto se relaciona a um efeito dose-resposta (Borrego et al, 2003; Fitze et al, 2003). 
Casos com HSCR/MEN2 são somente descritos em famílias com mutação no éxon 10 do gene RET. Um recente consórcio internacional reuniu dados clínicos e genéticos de 340 pacientes com mutações no éxon 10 (Frank-Raue K, 2011). Do total de 267 pacientes com dados disponíveis para HSCR, 20 (7,5\%) desenvolveram a doença, sendo estavam associados às mutações p.C609Y, p.C618R, p.C620R, p.C620G, p.C620Y.

Apesar de ser um evento relativamente raro, a manifestação de HSCR/CMT em familiares com mutação germinativa no gene RET é bastante intrigante do ponto de vista genético-molecular.

Isto porque esta situação conota à ação ativadora da mutação $R E T$ nos tecidos endócrinos envolvidos (tireóide, paratireóides, adrenais) e a uma simultânea ação inativadora nos neuroblastos do tecido entérico.

Estudos prévios mostraram que o desenvolvimento de HSCR em famílias com NEM2 seria influenciado pela associação com o SNP no RET rs1800858 (c.135G>A, p.A45A). A freqüência desse polimorfismo foi estudada em 312 casos com HSCR esporádica e foi verificada que era significativamente maior (76.3\%) do que entre os 312 controles saudáveis (26.6\%) (Fitze G, 1999; Borrego S, 1998).

No presente estudo, investigamos por seqüenciamento automático as regiões codificadoras e flanqueadoras do gene $R E T$ e mostramos que a manifestação de HSCR em uma extensa família com CMT familial não está associada à possível presença de uma segunda mutação germinativa (inativadora). 
Entretanto, observamos que o haplótipo TTCGTTAAAGC estava presente nos familiares estudados que desenvolveram HSCR e que estava ausente nos familiares com CMT e sem HSCR $(p=0,012)$.

Esses achados sugerem uma associação do haplótipo TTCGTTAAAGC com o desenvolvimento de HSCR nessa família e reforça dados anteriores que sugeriram que haplótipos funcionais de baixa penetrância, incluindo o polimorfismo rs1800858, estariam envolvidos no mecanismo de desenvolvimento da doença (Fitze G, 1999; Borrego S, 1998).

Em relação aos familiares aqui analisados que não desenvolveram HSCR, pudemos identificar em todos eles o "haplótipo mínimo" CATGTAdelT (rs2505533, rs72781232, rs2565206, rs1800858, rs1864404, rs3026750, rs34827976 e rs1800861).

Isto sugere, durante a fase embriológica, este haplótipo pode exercer uma ação potencialmente "protetora", impedindo assim a desativação do receptor RET em tecidos-específicos, tais como o tubo intestinal. Esta ação protetora do haplótipo permitiria a manutenção da expressão/função da proteína RET em um limiar de ativação adequado que evitaria o desenvolvimento da HSCR. 


\section{Conclusão}


Nossos dados demonstram ausência de segundas mutações inativadoras no gene RET nos casos NEM2/HSCR estudados. Entretanto, sugerem fortemente que haplótipos potencialmente funcionais e de baixa penetrância podem estar envolvidos no mecanismo de desenvolvimento do megacólon associado à MEN2, como previamente sugerido. 
8 Referências 
1. Abelin NMA, Gomes S, Ivanoff MT, Ezabella MCL, Hayashida $C Y$, Toledo SPA. Abordagem clínica e laboratorial do bócio uni-nodular sólido: vantagens da determinação da calcitonina sérica por métodos distintos. Arq Bras Endocrinol Metab, 1999; 43: 104-13.

2. Amiel J, Lyonnet S. Hirschsprung disease, associated syndromes, andgenetics: a review. J Med Genet, 38:729-39, 2001.

3. Amiel J, Sproat-Emison E, Garcia-Barcelo M, Lantieri F, Burzynski G, Borrego S, Pelet A, Arnold S, Miao X, Griseri P, Brooks AS, Antinolo G, de Pontual L, Clement-Ziza M, Munnich A, Kashuk C, West K, Wong KKY, Lyonnet S, Chakravarti A, Tam PKH, Ceccherini I, Hofstra RMW, Fernandez R, Forthe Hirschsprung Disease Consortium - Hirschsprung disease, associated syndromes and genetics: a review. J Med Genet 2008:45:1-14.

4. Attié $T$, Pelet A, Edery $P$, Eng $C$, Mulligan LM, Amiel J, Boutrand L, Beldjord C, Nihoul-Fékété $C$, Munnich A, et al. Diversity of RET protooncogene mutations in familial and sporadic Hirschsprung disease. Hum Mol Genet. 1995;4:1381-6.

5. Badner JA, Sieber WK, Garver KL, Chakravarti A. A genetic study of Hirschsprung disease. Am J Hum.Genet, 46:568-76, 1990. 
6. Bartsch DK, Hasse C, Schug C, Barth P, Rothmund M, Höppner W 2000 A RET double mutation in the germline of a kindred with FMTC. Exp Clin Endocrinol Diabetes 108:128-132

7. Baumgartner-Parzer SM, Lang R, Wagner L, Heinze G, Niederle B, Kaserer K, WaldhäusI W, and Vierhapper H. - Polymorphisms in Exon 13 and Intron 14 of the RET Protooncogene: Genetic Modifiers of Medullary Thyroid Carcinoma? J. Clin Endocrinol Metab 2005

8. Bolino A, Schuffenecker I, Luo Y, Seri M, Silengo M, Tocco T, Chabrier G, Houdent C, Murat A, Schlumberger M, Tourniaire J, Lenoir GM, Romeo G. RET mutations in exons 13 and 14 of FMTC patients. Oncogene 10: 2415-2419, 1995.

9. Borget I, De Pouvourville G, Schlumberger M. - Editorial: Calcitonin determination in patients with nodular thyroid disease. J Clin Endocrinol Metab. 2007 Feb;92(2):425-7.

10. Borrego S, Eng C, Sánchez B, Sáez ME, Navarro E, Antiñolo G. Molecular analysis of the ret and GDNF genes in a family with multiple endocrine neoplasia type $2 \mathrm{~A}$ and Hirschsprung disease. J Clin Endocrinol Metab. 1998;83:3361-4.

11. Borrego $S$, Wright FA, Fernández RM, Williams $N$, López-Alonso $M$, Davuluri R, Antiñolo G, Eng C - A Founding Locus within the RET ProtoOncogene May Account for a Large Proportion of Apparently Sporadic Hirschsprung Disease and a Subset of Cases of Sporadic Medullary Thyroid Carcinoma. Am J Hum Genet, 2003; 72:88-100. 
12. Brandi ML, Gagel RF, Angeli A, Bilezikian JP, Beck-Peccoz P, Bordi C, Conte-Devolx B, Falchetti A, Cheri RG, Libroia A, Lips CJM, Lombardi C, Mannelli M, Pacini F, Ponder BAJ, Raue F, Skogseid B, Tamburrano G, Thakker RV, Thompson NW, Tomassetti P, Tonelli F, Wells SAJr, Marx SJ. CONSENSUS: Guideline for diagnosis and therapy of MEN type 1 and type 2. J Clin Endocrinol Metab, 2001; 86: 5658-71.

13. Bugalho MJ, Cote GJ, Khorana S, Schultz PN, Gagel RF 1994 Identification of a polymorphism in exon 11 or the RET proto-oncogene. Hum Mol Genet 12:2263

14. Cebrian A, Lesueur F, Martin S, Leyland J, Ahmed S, Luccarini C, Smith PL, Luben R, Whittaker J, Pharoah PD, Dunning AM, and Ponder BAJ Polymorphisms in the Initiators of RET (Rearranged during Transfection) Signaling Pathway and Susceptibility to Sporadic Medullary Thyroid Carcinoma. J. Clin. Endocrinol. Metab. Nov 2005; 90: 6268 - 6274.

15. Ceccherini I, Hofstra RMW, Luo Y, Stulp RP, Barone V, Stelwagen T, Bocciardi R, Nijveen H, Bolino A, Seri M, Ronchetto P, Pasini B, Bozzano M, Buys CHCM, Romeo G 1994 DNA polymorphisms and conditions for SSCP analysis of the 20 exons of the ret proto-oncogene.

16. Chattopadhyay $P$, Pakstis AJ, Mukherjee $N$, lyengar $S$, Odunsi $A$, Okonofua F, Bonne-Tamir B, Speed W, Kidd JR, Kidd KK - Global survey of haplotype frequencies and linkage disequilibrium at the RET locus. Europ J Hum Genet 2003; 11, 760-769.

17. Costa, P; Domingues, R; Sobrinho, L G.; Bugalho, M J - RET Polymorphisms and Sporadic Medullary Thyroid Carcinoma in a Portuguese Population. Endocrine, 2005; 27: 239-244 
18. Dahia PLM, Toledo SPA, Mulligan LM, Maher ER, Grossman AB, Eng C 1997 Mutation analysis of glial cell line-derived neurotrophic factor (GDNF), a ligand for the RET/GDNF receptor complex in sporadic phaeochromocytomas. Cancer Res 57:310-313

19. de Groot JWB, Links TP, Plukker JTM, Lips CJM, and Hofstra RMW. RET as a Diagnostic and Therapeutic Target in Sporadic and Hereditary Endocrine Tumors. Endocr Rev, August 1, 2006; 27(5): 535 - 560.

20. Decker RA, Peacock ML. - Occurrence of MEN 2a in familial Hirschsprung's disease: a new indication for genetic testing of the RET proto-oncogene. Pediatr Surg. 1998; 33:207-14.

21. Donnis-Keller H, Dou S, Chi D, Carlson KM, Toshima K, Lairmore TC, Howe JR, Moley JF, Goodfellow P, Wells SA Jr. Mutations in RET protooncogene are associated with MEN2A and FMTC. Hum Molec Genet, 1993; 2: 851-56.

22. Duerr EV, Gimm O, Neuberg DS, Kum JB, Clifford SC, Toledo SPA, Maher ER, Dahia PLM, Eng C. Differences in Allelic Distribution of Two Polymorphisms in the VHL-Associated Gene CUL2 in Pheochromocytoma Patients without Somatic CUL2 Mutations. J. Clin. Endocrinol. Metab. Sep 1999; 84: 3207 - 3211.

23. Edery P, Pelet A, Mulligan LM, Abel L, Attié T, Dow E, Bonneau D, David $A$, Flintoff $W$, Jan $D$, et al. - Long segment and short segment familial Hirschsprung's disease: variable clinical expression at the RET locus. J Med Genet. 1994;31:602-6. 
24. Edery P, Pelet A, Mulligan LM. Long segment familial Hirschsprung's disease: variable clinical expression at the RET locus. J Med Genet, 31:602-13, 1994.

25. Elisei R, Cosci B, Romei C, Agate L, Piampiani P, Miccoli P, Berti $P$, Basolo F, Ugolini C, Ciampi R, Nikiforov $Y$, and Pinchera A. Identification of a Novel Point Mutation in the RET Gene (Ala883Thr), Which Is Associated with Medullary Thyroid Carcinoma Phenotype Only in Homozygous Condition. J Clin Endocrinol Metab. Nov 2004; 89: 5823-27.

26. Elisei R, Cosci B, Romei C, Bottici V, Sculli M, Lari R, Barale R, Pacini F, and Pinchera A. RET Exon 11 (G691S) Polymorphism Is Significantly More Frequent in Sporadic Medullary Thyroid Carcinoma Than in the General Population. J Clin Endocrinol Metab, Jul 2004; 89: 3579 - 3584

27. Eng C, Crossey PA, Mulligan LM, Healey CS, Houghton C, Prowse A, Chew SL, Dahia PL, O'Riordan JL, Toledo SP, et al.- Mutations in the RET proto-oncogene and the von Hippel-Lindau disease tumour suppressor gene in sporadic and syndromic phaeochromocytomas. J Med Genet. 1995 ;32: 934-937

28. Eng C - Ret proto-oncogene in the development of human câncer. J Clin Oncol. 1999; 17: 380-404.

29. Ezabella MCL, Hayashida CY, Abelin NMA, Toledo SPA. Neoplasias Endocrinas Múltiplas. In: Medeiros-Neto G, editor. Moléstias Hereditárias do Sistema Tireoideano. 1ํ Edição. São Paulo: Roca, 1996: 225-42.

30. Ezabella MC, Hayashida CY, Bisi H, Leite MO, Borelli A, Abelin NM, Cordeiro AC, Camargo RY, Toledo SP.- Early detection of medullary thyroid carcinoma in multiple endocrine neoplasia type II Rev Hosp Clin Fac Med Sao Paulo. 1990; 45:105-109. 
31. Farndon, J. R.; Leight, G. S.; Dilley, W. G.; Baylin, S. B.; Smallridge, R. C.; Harrison, T. S.; Wells, S. A., Jr. Familial medullary thyroid carcinoma without associated endocrinopathies: a distinct clinical entity. Brit $J$ Surg. 73: 278-281, 1986.

32. Feldman GL, Edmonds MW, Ainsworth PJ, Schuffenecker I, Lenoir GM, Saxe AW, Talpos GB, Roberson J, Petrucelli N, Jackson CE. - Variable expressivity of familial medullary thyroid carcinoma (FMTC) due to V804M (GTG>ATG) mutation. Surgery. 2000;128:93-8.

33. Fernández RM, Peciña A, Antiñolo G, Navarro E, Borrego S. - Analysis of RET polymorphisms and haplotypes in the context of sporadic medullary thyroid carcinoma. Thyroid 2006;16: $411-417$

34. Fitze G, Appelt H, Konig IR, GorgensH, Stein U, Walther W, Gossen M, Schreiber M, Ziegler A, Roesner D, SchackertHK - Functional haplotypes of the RET proto-oncogene promoter are associated with Hirschsprung disease (HSCR). Hum Molec Genet. 2003; 12: 3207-3214

35. Fitze G, Cramer J, Serra A, Schreiber M, Roesner D, Schackert HK. Within-gene interaction between c.135 G/A genotypes and RET protooncogene germline mutations in HSCR families. Eur $J$ Pediatr Surg. 2003;13:152-7.

36. Fitze G, Schierz M, Bredow J, Saeger HR, Roesner D, Schackert HK Various Penetrance of Familial Medullary Thyroid Carcinoma in Patients With RET Protooncogene Codon 790/791 Germline Mutations. Ann Surg. 2002; 236: 570-575. 
37. Fitze G, Schierz M, Kuhlisch E, Schreiber M, Ziegler A, Roesner D, Schackert HK - Novel intronic polymorphisms in the RET proto-oncogene and their association with Hirschsprung disease. Hum Mutat 2003; 22: $177-177$.

38. Fitze G, Schreiber M, Kuhlisch E, Schackert HK, Roesner D. Association of RET protooncogene codon 45 polymorphism with Hirschsprung disease. Am J Hum Genet. 1999;65:1469-73.

39. Fitze G, Schreiber M, Kuhlisch E, Schackert HK, Roesner D - Association of RET Protooncogene Codon 45 Polymorphism with Hirschsprung Disease. Am J Hum Genet. 1999; 65: 1469-1473.

40. Frank-Raue K, Rybicki LA, Erlic Z, Schweizer H, Winter A, Milos I, Toledo SP, Toledo RA, Tavares MR, Alevizaki M, Mian C, Siggelkow H, Hüfner M, Wohllk N,Opocher G, Dvořáková S, Bendlova B, Czetwertynska M, Skasko E, Barontini M, Sanso G, Vorländer C, Maia AL, Patocs A, Links TP, de Groot JW, Kerstens MN, Valk GD, Miehle K, Musholt TJ, Biarnes J, Damjanovic S, Muresan M, Wüster C, Fassnacht M, Peczkowska M, Fauth C, Golcher H, Walter MA, Pichl J, Raue F, Eng C, Neumann HP; and for the International RET Exon 10 Consortium. Risk profiles and penetrance estimations in multiple endocrine neoplasia type $2 \mathrm{~A}$ caused by germline RET mutations located in exon 10. Hum Mutat. 2011 Jan;32(1):51-8.

41. Gagel RF. The impact of gene mapping techniques on the management of multiple endocrine neoplasia type 2. Trends Endocr Metab, 1991; 2: 19-25.

42. Gimm O. Multiple Endocrine Neoplasia Type 2: Clinical Aspects. In: Dahia PLM, Eng C, editors. Genetic Disorders of Endocrine Neoplasia. 1ํEdição. Front Horm Res Basel, Karger, 2001: 103-30 
43. Hayashida CY, Alves VAF, Kanamura CT, Ezabella MCL, Abelin NMA, Nicolau W, Bisi $H$, Toledo SPA. Immunohistochemistry of medullary thyroid carcinoma and C-cell hyperplasia by an affinity-purified antihuman calcitonin antiserum. Cancer, 1993; 72: 1356 -63.

44. Herfarth KK, Bartsch D, Doherty GM, Wells SA, Lairmore TC. - Surgical management of hyperparathyroidism in patients with multiple endocrine neoplasia type 2A. Surgery, 1996; 120: 966-74.

45. Hirschsprung $H$. Stuhlträgheit neugeborener in folge von dilatation und hipertrophic des colons. Jahrb Kinderheilkd, 27:1-27, 1888.

46. Hoff AO, Cote GJ, Gagel RF. Multiple endocrine neoplasias. Annu Rev Physiol, 2000; 62: 377-400.

47. Kahraman T, Groot JWB, Rouwe C, Hofstra RMW, Links TP, Sijmons RH, Plukker JTM. Acceptable age for prophylatic surgery in children with multiple endocrine neoplasia type 2A. Eur J Surg Oncol, 2002; 29: 331-35.

48. Kloos RT, Eng C, Evans DB, Francis GL, Gagel RF, Gharib H, Moley JF, Pacini F, Ringel MD, Schlumberger M, Wells SA Jr. (American Thyroid Association Guidelines Task Force). Medullary thyroid cancer: management guidelines of the American Thyroid Association. Thyroid. 2009; 19:565-612. Review. Erratum in: Thyroid. 2009 Nov;19(11):1295.

49. Lesueur, F.; Cebrian, A.; Cranston, A.; Leyland, J.; Faid, T. M.; Clements, M. R.; Robledo, M.; Whittaker, J.; Ponder, B. A. J.:Germline homozygous mutations at codon 804 in the RET protooncogene in medullary thyroid carcinoma/multiple endocrine neoplasia type 2A patients. J Clin Endocr Metab. 90: 3454-3457, 2005. 
50. Lombardo, F.; Baudin, E.; Chiefari, E.; Arturi, F.; Bardet, S.; Caillou, B.; Conte, C.; Dallapiccola, B.; Giuffrida, D.; Bidart, J.-M.; Schlumberger, M.; Filetti, S. : Familial medullary thyroid carcinoma: clinical variability and low aggressiveness associated with RET mutation at codon 804. J Clin Endocr Metab. 87: 1674-1680, 2002.

51. Longuini VC, 2007. Dissertação do Programa de Aprimoramento profissional; HC - FMUSP / FUNDAP - 2007.

52. Maksoud, JG. Moléstia de Hirschsprung. In Cirurgia Pediátrica, Ed Revinter I ed. 68:781-94, 1998.

53. Marx SJ, Simmonds WF - Hereditary hormone excess: genes, molecular pathways, and syndromes. Endocr. Rev. 2005; 26: 615-61.

54. Marx SJ-Molecular genetics of multiple endocrine neoplasia types 1 and 2 . Nat. Rev. Cancer. 2005; 5:367-75.

55. Mc Whinney, SR et al. Intronic Single Nucleotide Polymorphisms in the RET Protooncogene Are Associated with a Subset of Apparently Sporadic Pheochromocytoma and May Modulate Age of Onset. J Clin Endocrinol Metab. Oct 2003; 88: 4911 - 4916.

56. Menacho IP, Burzynski GM, Groot JM, Eggen BJL, HofstraRMW Current concepts in RET-related genetics, signaling and therapeutics. Trends Genet 2006; 22: 627-636.

57. Mendonca BB, Arnhold IJ, Nicolau W, Avancini VA, Boise W. - Cushing's syndrome due to ectopic ACTH secretion by bilateral pheochromocytomas in multiple endocrine neoplasia type $2 \mathrm{~A}$. $N$ Engl $J$ Med. 1988;319:1610 - 1611. 
58. Mendonça BB, Arnhold IJP, Nicolau W, Avancini VAF, Bloise W 1988 Cushing's syndrome due to ectopic ACTH secretion by bilateral pheochromocytomas in multiple endocrine neoplasia type 2A. $N$ Engl J Med 319:1610-1611

59. Miller AS, Dykes DD, Polesky HF 1988 A simple salting out procedure for extracting DNA from human nucleated cells. Nucleic Acids Res 16:12-15

60. Montenegro FL - Informação pessoal, 2005.

61. Moore SW, Zaahl MG. Multiple endocrine neoplasia syndromes, children, Hirschsprung's disease and RET. Pediatr Surg Int. 2008;24:521-30.

62. Mulligan LM, Eng C, Attié T, Lyonnet S, Marsh DJ, Hyland VJ, Robinson BG, Frilling A, Verellen-Dumoulin C, Safar A, et al. - Diverse phenotypes associated with exon 10 mutations of the RET proto-oncogene. Hum $\mathrm{Mol}$ Genet. 1994 Dec;3:2163-7

63. Mulligan LM, Kwok JB, Healey CS, Elsdon MJ, Eng C, Gardner E, Love DR, Mole SE, Moore JK, Papi L, Ponder MA, Telenius H, Tunnacliffe A, Ponder BA 1993 Germ-line mutations of the RET proto-oncogene in multiple endocrine neoplasia type 2 A. Nature 363:458-460

64. Neumann HP, Bausch B, McWhinney SR, Bender BU, Gimm O, Franke G, Schipper J, Klisch J, Altehoefer C, Zerres K, Januszewicz A, Eng C, Smith WM, Munk R, Manz T, Glaesker S, Apel TW, Treier M, Reineke M, Walz MK, Hoang-Vu C, Brauckhoff M, Klein-Franke A, Klose P, Schmidt $\mathrm{H}$, Maier-Woelfle M, Peçzkowska M, Szmigielski C, Eng C; FreiburgWarsaw-Columbus Pheochromocytoma Study Group. Germ-line mutations in nonsyndromic pheochromocytoma. $N$ Engl $J$ Med. 2002;346:1459-66. 
65. Niccoli-Sire P, Murat A, Baudin E, Henry J, Proye C, Bigorgne J, Modigliani E, Conte-Devolx B. Early or prophylatic thyroidectomy in MEN2/FMTC gene carriers: results in 71 thyroidectomized patients. Eur $J$ Endocrinol, 1999; 141: 468-74.

66. Nunes AB, Ezabella MCL, Pereira AC, Krieger JE, Toledo SPA. A novel Val648lle substitution in RET proto-oncogene observed in a Cys634Arg multiple endocrine neoplasia type $2 \mathrm{~A}$ kindred presenting with an adrenocorticotropin-producing pheochromocytoma. $J$ Clin Endocrinol Metab, 2002; 87: 5658-61.

67. Nunes $\mathrm{AB}$. Identificação de mutações do proto-oncogene RET associadas à forma hereditária do carcinoma medular de tireóide. 2002. Tese Doutorado, FMUSP.

68. Passarge E. The genetics of Hirschsprung's disease: evidence for heterogeneous etiology and a study of sixty-three families. $N$ Engl J. Med. 276:138-43, 1967

69. Patocs, A.; Valkusz, Z.; Igaz, P.; Balogh, K.; Toth, M.; Varga, I.; Racz, K. : Segregation of the V804L mutation and S836S polymorphism of exon 14 of the RET gene in an extended kindred with familial medullary thyroid cancer. Clin. Genet. 63: 219-223, 2003.

70. Pelet A, Pontual L, Clément-Ziza M, Salomon R, Mugnier C, Matsuda F, Lathrop M, Munnich A, Feingold J, Lyonnet S, Abel L, Amiel J Homozygosity for a frequent and weakly penetrant predisposing allele at the RET locus in sporadic Hirschsprung disease. J Med Genet 2005; 42:e18 
71. Robledo M, Gil L, Pollán M, Cebrián A, Ruíz S, Azañedo M, Benitez J, Menárguez J, Rojas JM - Polymorphisms G691S/S904S of RET as Genetic Modifiers of MEN 2A. Cancer Res 2003; 63: 1814 - 1817

72. Rowe MI, O`Neill JA, Grosfeld JL, Fonkalsrud EW, Coran AG. Hirschsprung disease. In Essential of Pediatric Surgery, Ed. Mosby, I ed. 67:586-95, 1995.

73. Santos, MACG - Detecção e rastreamento de mutações no protooncogene RET em pacientes com neoplasia endócrina múltipla tipo 2 por meio de eletroforese em gel sensível à conformação. Tese de Mestrado, FMUSP, 2007

74. Santos MA, Nunes AB, Abelin N, Ezabella MC, Toledo RA, Lourenco Junior D, Hayashida CY, Fonseca II, Toledo SPA - Genetic screening of multiple endocrine neoplasia type 2: experience of the USP Endocrine Genetics Unit. Arq Bras Endocrinol Metabol. 2006;50:7-16.

75. Silva AMA, Maciel RMB, Silva MRD, Toledo SRC, Carvalho MB, Cerutti JM. A Novel germ-line mutation in RET Exon 8 (Gly533Cys) in a large kindred with familial medullary thyroid carcinoma. J Clin Endocrinol Metab, 2003; 88: 5438-43.

76. Skinner MA, Moley JA, Dilley WG, Owzar K, Debenedetti MK, Wells SA. Prophylactic thyroidectomy in multiple endocrine neoplasia type $2 \mathrm{~A} . \mathrm{N}$ Engl J Med. 2005; 353:1105-13.

77. Stratakis CA, Marx SJ - Multiple endocrine neoplasias in the era of translational medicine. Horm Metab Res. 2005;37:343-6. 
78. Tavares MR - Informação pessoal, 2005.

79. Tessitore A, Sinisi AA, Pasquali D, Cardone M, Vitale D, Bellastella A, Colantuoni V 1999 A novel case of multiple endocrine neoplasia type 2A associated with two de novo mutations of the RET proto-oncogene. J Clin Endocrinol Metab 84:3522-3527

80. Thakker RV - Multiple Endocrine Neoplasia-Syndromes of the Twentieth Century. J Clin Endocrinol Metab, Aug 1998; 83: 2617 - 2620

81. Toledo, RA et al in press, 2007- livro do HC, Editora Roca; editora de endocrinologia: Dra B.B. Mendonça

82. Toledo, RA et al - Neoplasias Endócrinas Múltiplas. In: Tratado de Clínica Médica. Endocrinologia, ed. Mendonça BB, 2009

83. Toledo RA, Wagner SM, Coutinho FL, Lourenço DM Jr, Azevedo JA, Longuini VC, Reis MT, Siqueira SA, Lucon AM, Tavares MR, Fragoso MC, Pereira AA, Dahia PL, Mulligan LM, Toledo SP. High penetrance of pheochromocytoma associated with the novel C634Y/Y791F double germline mutation in the RET protooncogene. $J$ Clin Endocrinol Metab 2010;95: 1318-1327.

84. Toledo SPA, Abelin NMA, Ezabella MCL, Hayashida CY, Dahia PM. Neoplasias Endocrinas Múltiplas. In: Wajchenberg BL, editor. Tratado de Endocrinologia Clínica. São Paulo: Roca, 1992: 943-64. 
85. Toledo SPA, Santos MA, Toledo RA, Lourenco Jr DM - .Impact of RET proto-oncogene analysis on the clinical management of multiple endocrine neoplasia type 2. Clinics 2006;61:59-70.

86. Torfs CP. An epidemiological study of Hirschsprung disease in a multiracial California population. The Third International Meeting: Hirschsprung disease and related neuro-cristopathies. Evian, France, 1998.

87. Volante M 2007. Sporadic C-cell hyperplasia associated with multinodular goiter. Pahtologica; 2006 , 98: 160-163.

88. Wells SA Jr, Franz C. Medullary carcinoma of the thyroid gland. World $J$ Surg, 2000; 24: 952-956.

89. You YN, Lakhani V, Wells SA, Moley JF. - Medullary thyroid cancer. Surg Oncol Clin N Am. 2006;15:639-60. 